\title{
الجمال والالتزام في الفن الإسلامي
}

\section{مجاهد مصطفى بكجت}

مقدمة: - مق

هذا بحث في الأدب و النقد دفعي إلى اختياره نزوع كثير من النقاد، قديماً و حديثاً إلى محاولة الفصل بين الجمال الذي هو عنوان كل شيء خلقه الله، والدين الذي جــــاء

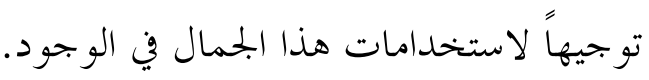

وقد تناول هذا الموضوع عدد من الذين كتبوا في بجال الأدب الإسلامي ضــمن كتبهم وأبحاثهم، ولكن هدف هذا البحث يركز على بيان صلة الإسلام بالجمـــال في بحال الأدب و الفن بصفة خاصة. ومن الذين تناولوا الموضوع بشكل مباشر: الأســاذ سيد قطب في "التصوير الفين في القرآن"، وقد ركز على الجمال الفي في القرآن فقط، ومنهم الدكتور عبد الفتاح رواس قلعجي في "مدخل إلى علم الجمال الإسلامي" الذي ركّز فيه على الفن المعماري في الإسلام، وردّ على من حاول الفصل بـــين الإســاملام

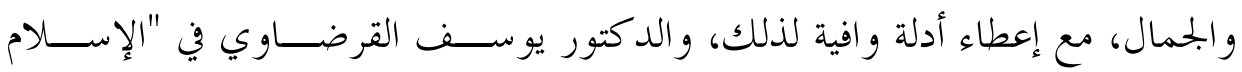
و الفن"، و الدكتور محسن عبد الحميد في "الفنون الجمميلة مــنـ المنظـــور الإســـلامي"، وصالح أحمد الشامي في "الفن الإسلامي"، ومنهم الشيخ محمد محمود عبد الــرحمن في

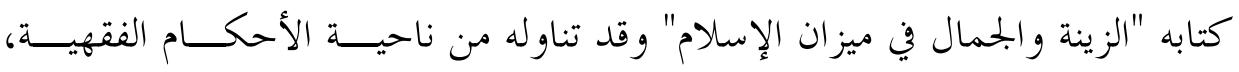
و جهودهم متميزة في مضامينها وقيمتها العلمية، و إن كانت ذات طابع خاص و أهداف محددة.

وقد سلكت في هذا البحث منهجاً وصفياً وتحليلياً، أوردت فيه الآراء المختلفة، ثم بينت -بعد المناقشة- رأي الإسلام فيها. وقسمته إلى تمهيد، وثلاثة مباحث، و خايتمة.

"الأستاذ بأكاديمية الدراسات الإسلامية بجامعة ملايا. البريد الإلكتروني: mujahidbahjat@hotmail.com 


$$
\text { في التمهيد عرفت الجمال والالتزام و الفن لغةً واصطلاحاً. }
$$

وي المبحث الأول: تناولت علاقة الإسلام بالجمال، مبيناً مفهوم الجمال و اهتمام

الإسلام به، وعلاقة الجمال بالتوحيد وغايته، وبحالات جمال الكون في القرآن الكريم.

وفي المبحث الثاني: قدمت رؤية نقدية إسلامية لمفهوم الالتزام، وتناولت المسؤولية

في القرآن و القواعد الشرعية، والجممال بين الذاتية والموضوعية، والالتزام و الفن.

وفي المبحث الثالث: درست الأسلوب القرآني بين جمال اللفظ وجهــلال المعـنى

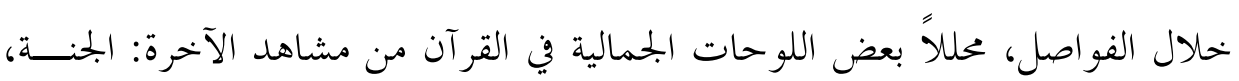
و النار . n

ووفي الخاتمة ذكرت النتائج التي توصل إليها البحث.

\section{تمهيد}

تعريف الجمال و الالتز ام و الفن:

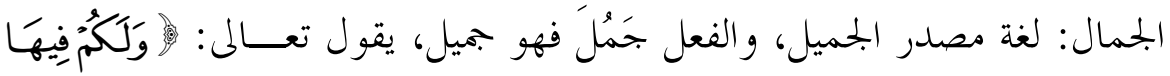

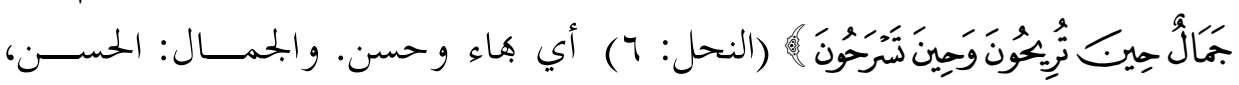

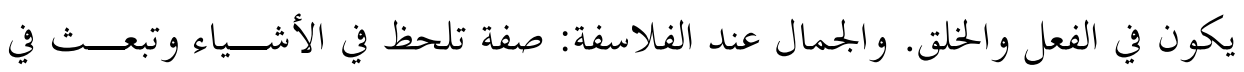

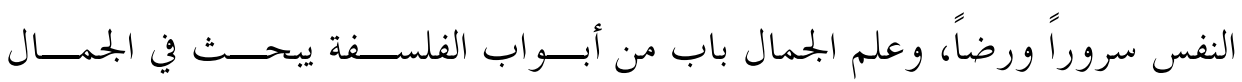
ومقاييسه و نظرياته.'

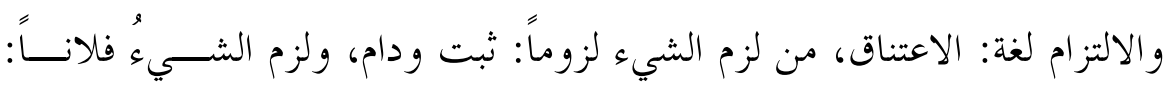

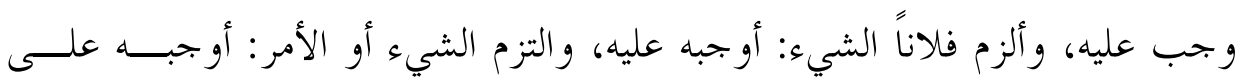

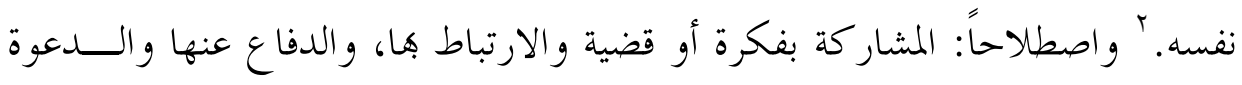


والعمل لها. وهي نظرية أدبية ولدت مع النظريات السياسية الجديدة، وأصــبحت في

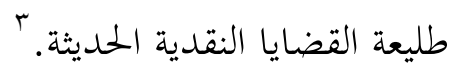

و الفن لغة: الضرب واللون من الشيء، والجمع فنون وأفنان. وتوسعت المعــاجم

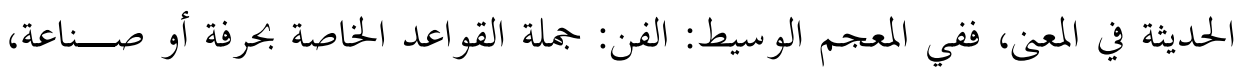

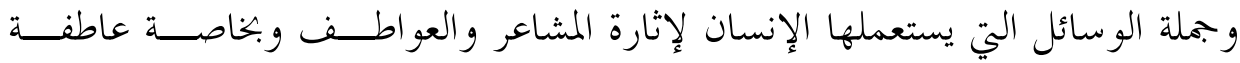

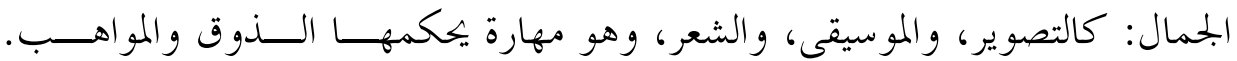

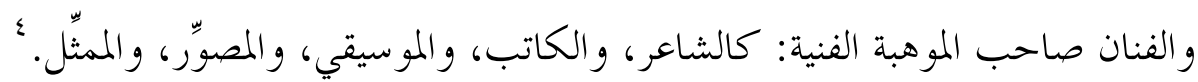
المعاني التي تدور حولها كلمة فن هي: التزيين، والتنويع، والإتيان بالجديد المعجب.

يقول العقاد: الفن هو الخطط واللون، ومنه التفنين .معــنى: التــزيين و التزويــق، والأفانين .معنى: الفروع أو الضروب، وهكذا كل ما ينظر بالأعين أو يدرك بالأفكار. ويرى عبد الرحمن حبنكة الميداين أن "الجمال شيء يصـــعب تحديـــده، وركـــن باستطاعة النفوس أن تحس به وتتذوقه متى أدركته." وهو: "دقيق العناصر متشابكها،

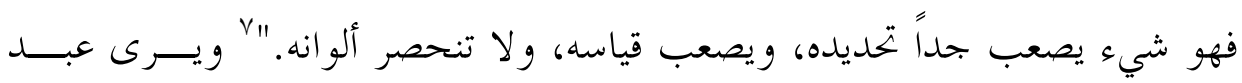

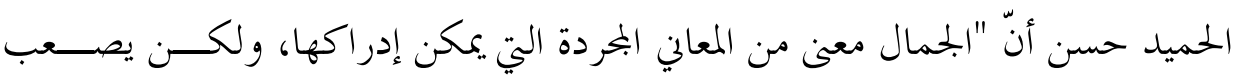

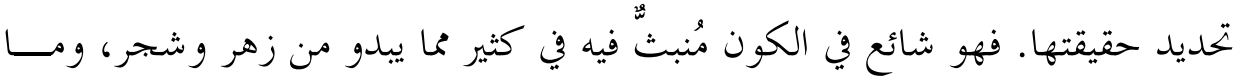

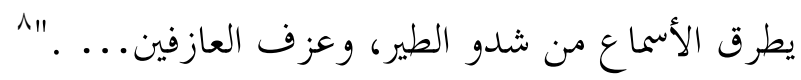

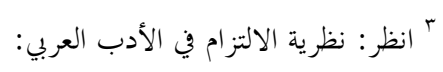

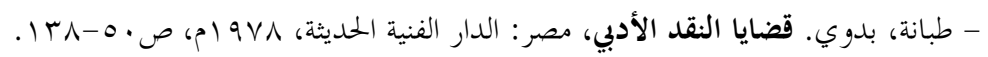

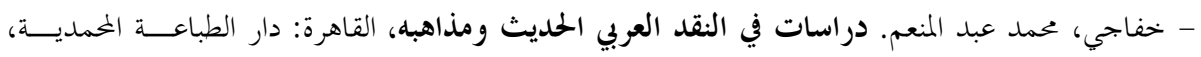

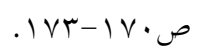
" المعجم الوسيط، مرجع سابق، مادة (فنن).

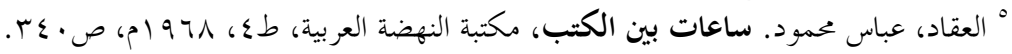

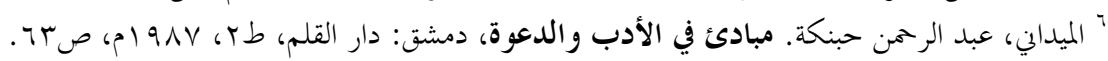

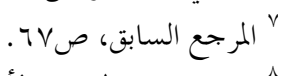
^ حسن، عبد الحميد. الأصول الفنية للأدب، القاهرة: مكتبة الأنخلو المصرية، طب، عج9 (1م، ص. ؟. 
وقد وردت في القرآن مصطلحات أخرى تدل على الجمال بقســـميه: المـــادي، و المعنوي، و منها: الإتقان، و الإحسان، و التسوية، و الاتساق، و التقويم، و التعديل، وعدم التفاوت، و وغيرها.

\section{أولاً: الجممال: أهميته، وغايته، وبجالاته}

\section{ا ـ ا مفهوم الجمال واهتمام الإسلام به:}

مفهو م الجمال في الإسلام واسع ومتنوع و متعدد الجلوانب، فهو مفهـــوم شـــــلي

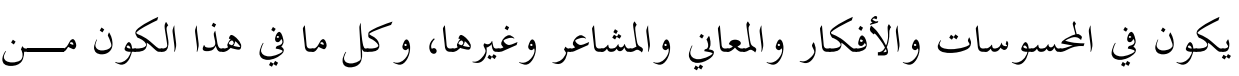

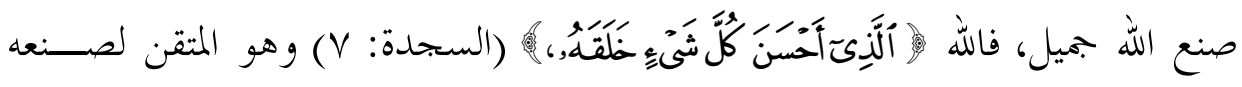

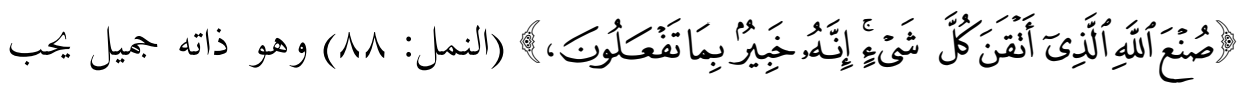

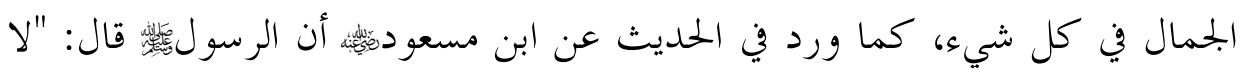

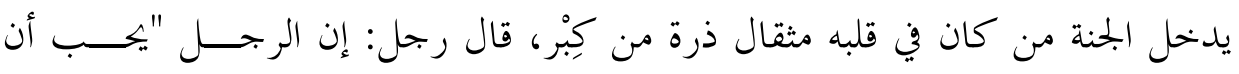

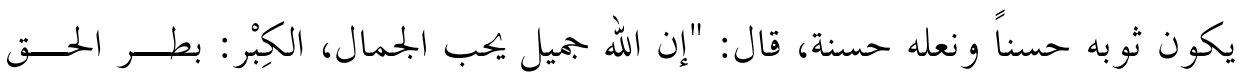

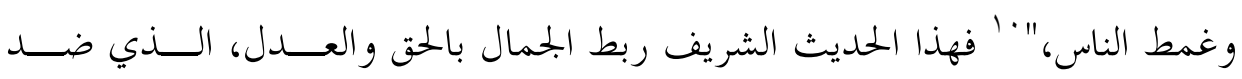

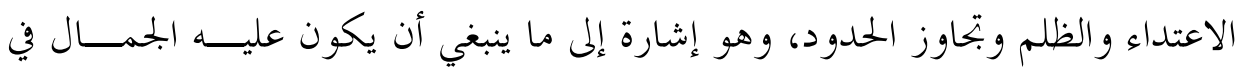
جميع سلوك البشر من ضرورة مطابقة جمال الظاهر لجمال الباطن. واهتمام الإســلام

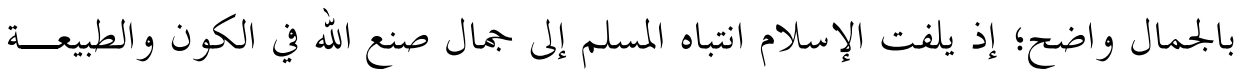

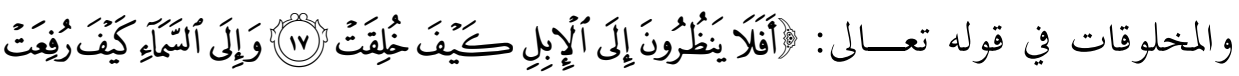

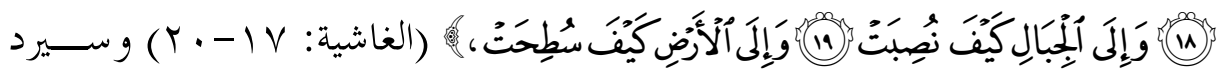
تفصيل ذلك في بحالات الجمال في الطبيعة.

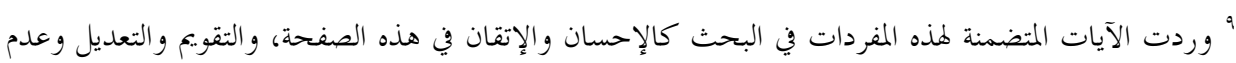

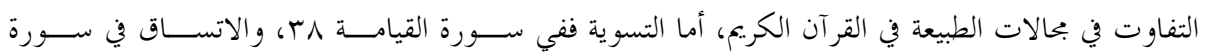
الانشقاق(1) (1).

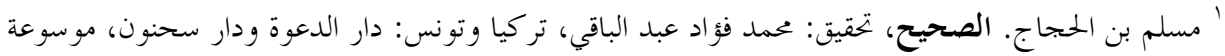

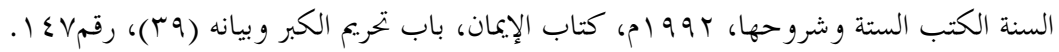




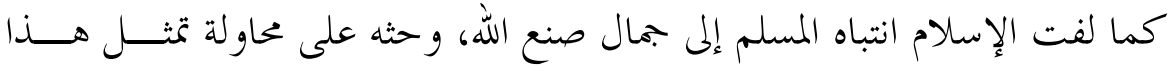

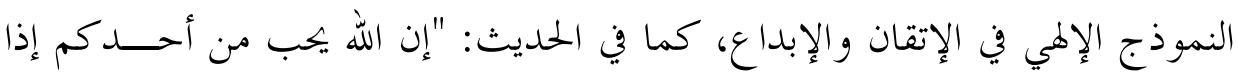

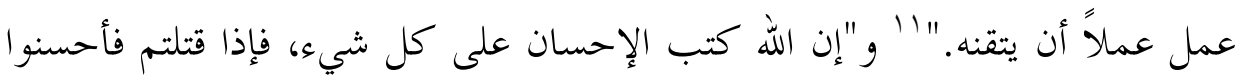

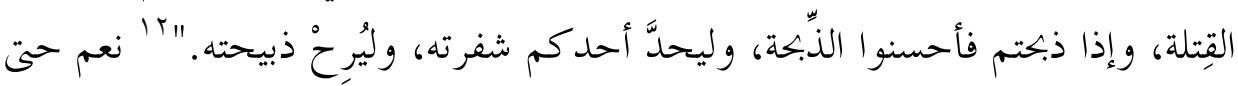

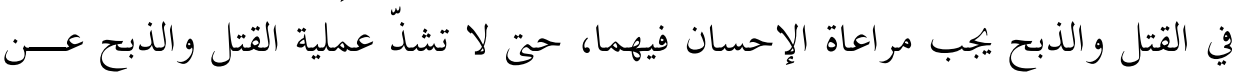

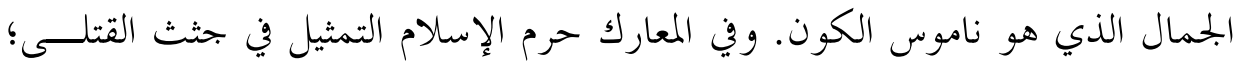
لأن في ذلك ما ينافي الجمال.

وحرص الإسلام على المحافظة على الجمال الظاهر حتى في ميدان القتال حين يكثر

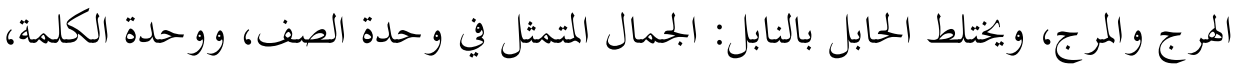

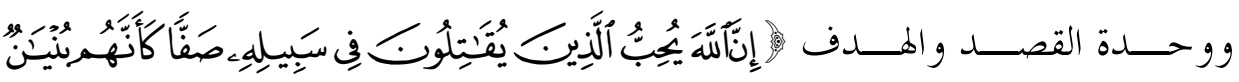

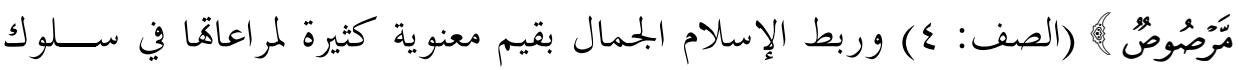

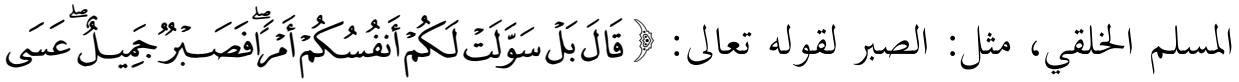

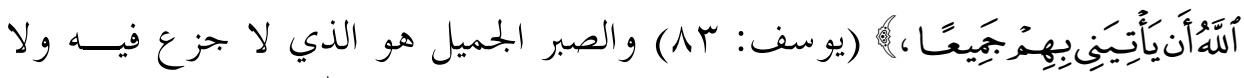

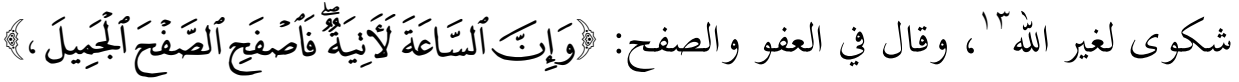

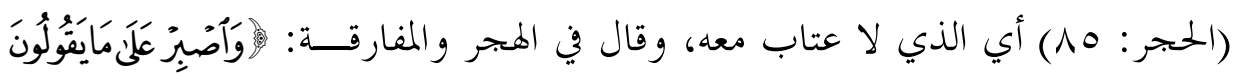

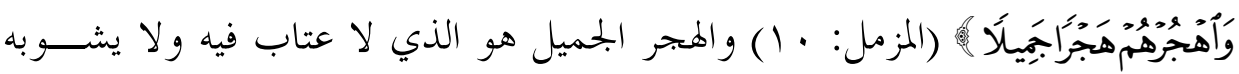
أي شتم.

وهكذا نرى الإسلام يهتم بالمجمال في كل شيء، ويدعو الإنســان المســلم إلى إلى

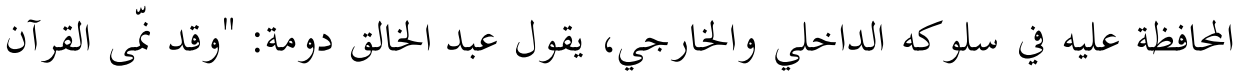

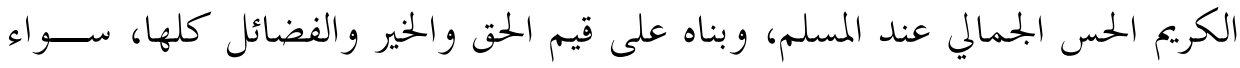

"ا البيهقي، أبو بكر أممد بن الحسين. شعب الإيمان، تحقيق: عمد السعيد بسيوني، بيروت: دار الكتب العلميـة،

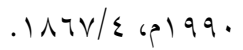

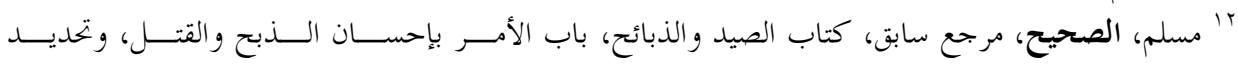

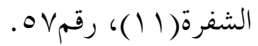

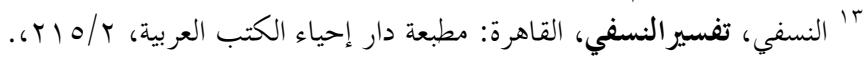

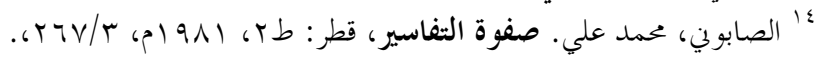




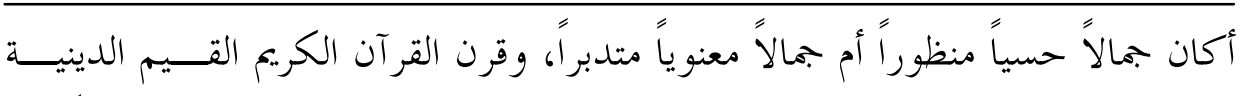

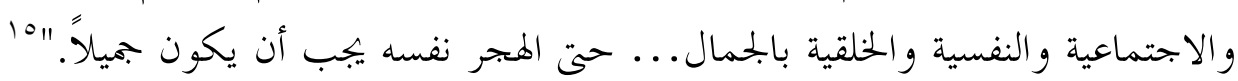
وهذا الاهتمام الإسلامي الرفيع بالجمال استهوى الدكتور عماد الدين خليل فقـــال:

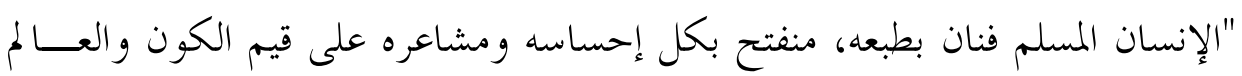

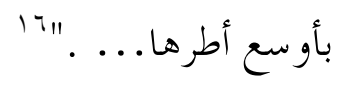

\section{Y. ع علاقة الجممال بالتوحيد و غايته وهدفه:}

الجمال مطلب توحيدي يراد تحققه في الدنيا والآخرة؛ لأن الله هو الجميل ويكـــبـ

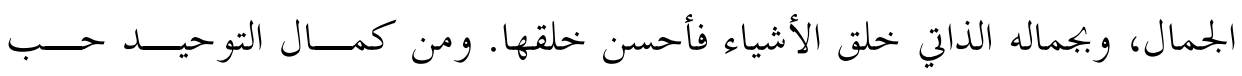

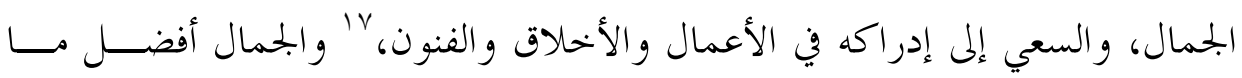
يرجو المؤمن حصوله يوم القيامة، ويتمثل في النظر إلى جمال و جههه سبحانه وتعـــالى:

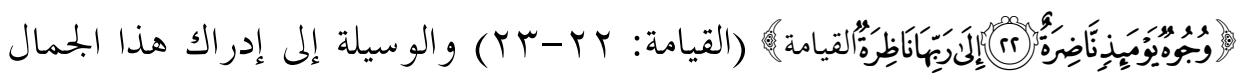

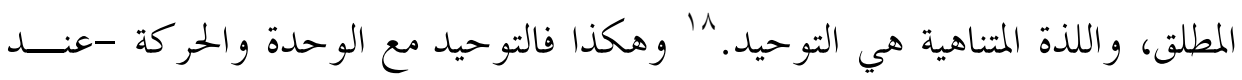
بعض الدارسين - من منطلقات الجمال. 19

و إذا حللنا معنى كلمة التوحيد "أشهد أن لا إله إلا الله" نرى أهنا تنطـــوي علــى

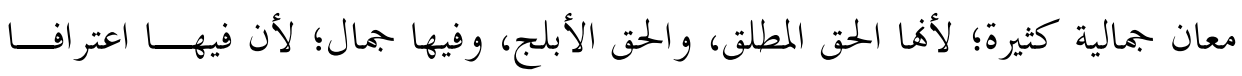

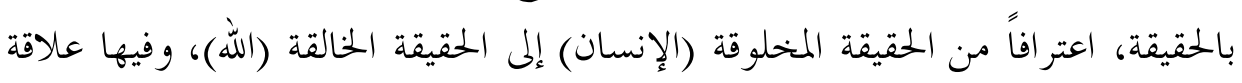

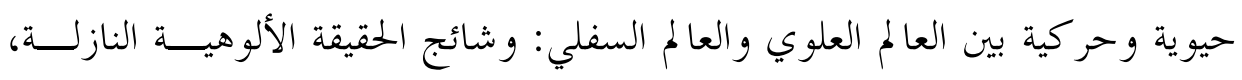
و العبودية الصاعدة اللتين تلتقيان في ترابط و انسجام دائمين.

تأمل في (أشهد) بصيغة الحاضر الدائمة التجدد والمثول أمام بصر المؤمن وبصيرته في كل وقت، ووفي كل مكان، و في كل حالة. وتأمل حركة الصورة في (لا إله إلا الله)

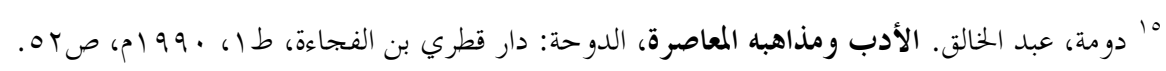

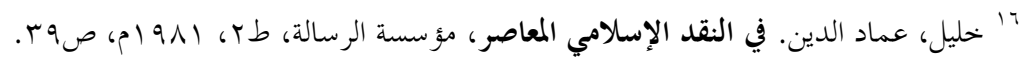

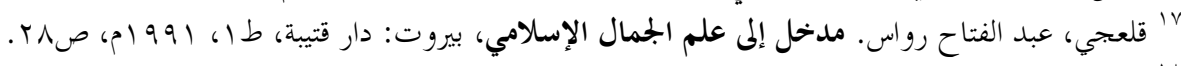

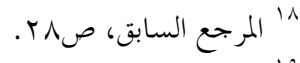

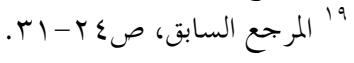


الصورة الحالة والزائلة في النفي والإثبات، ولاحظ الحركة فيها: إبعاد ففــــاغ وزوال

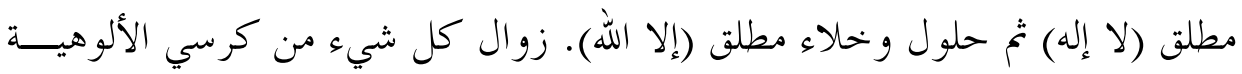

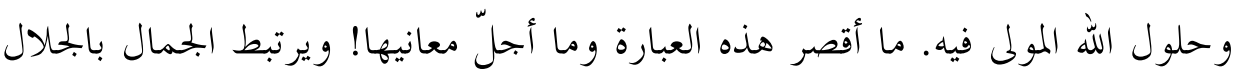

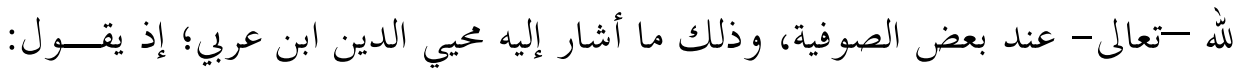

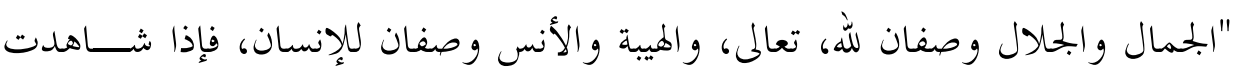

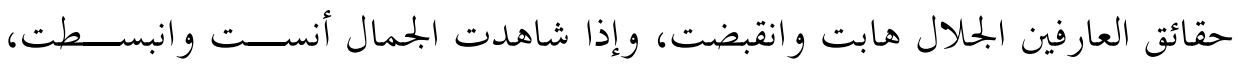

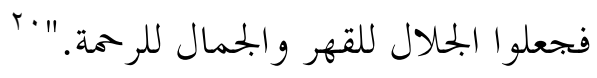

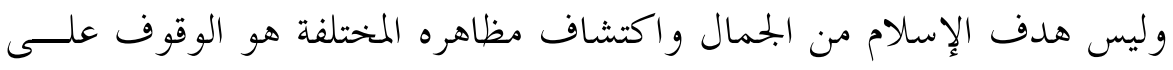

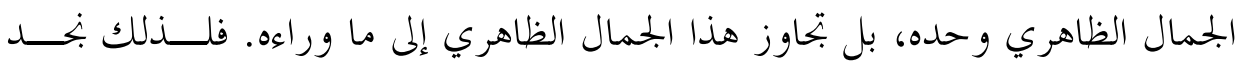

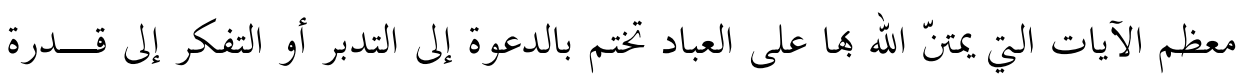
الله التي أو جددت هذه المظاهر.

ففي معرض الحديث عن اللباس الذي جعله الله ستراً وجمالاً للإنسان يقول

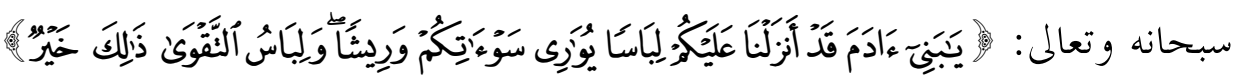

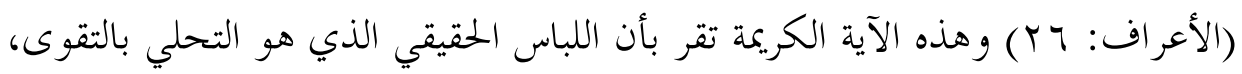
خير من اللباس الظاهري.

ومهما يكن الجمال خلاباً وفاتناً فيجب أن يتناسق مع الجمال الباطني حتى يحبه

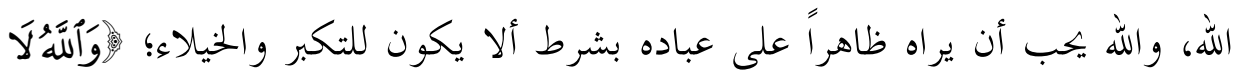

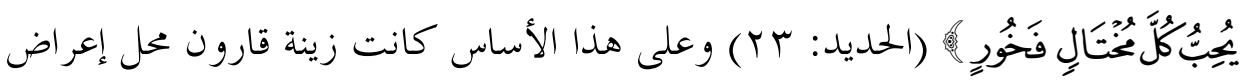

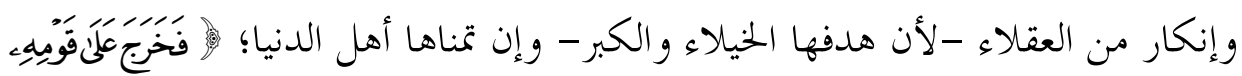

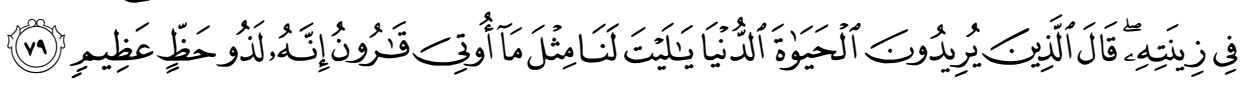

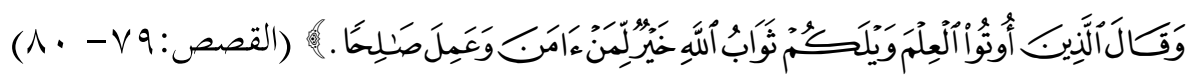

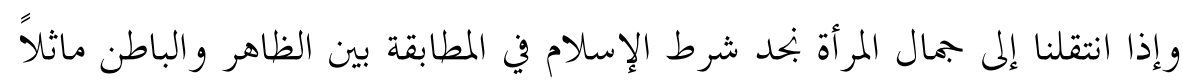

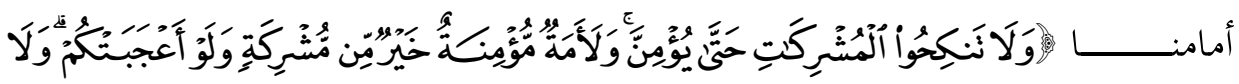




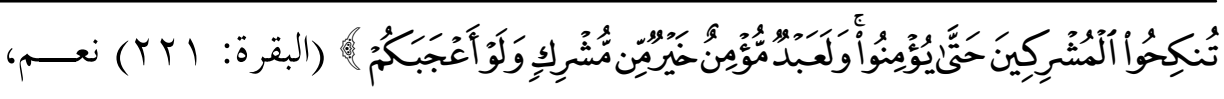

ولو أعجبتكم بحسنها و جمالها الظاهري.

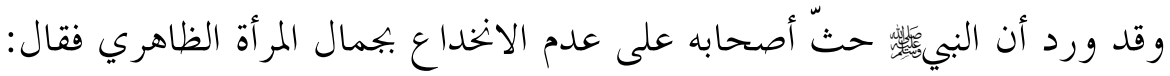

"إياكم وخضراء الدمن، قيل: وما خضراء الدمن يا رسول الله؟ قال المرأة الحســـناء في

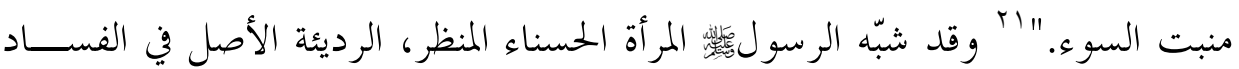
و الإضرار بالنبتة، تنبت في أرض ملوثة بالأقذار؛ إذ تبدو جميلة في منظرها، ســـريعة في

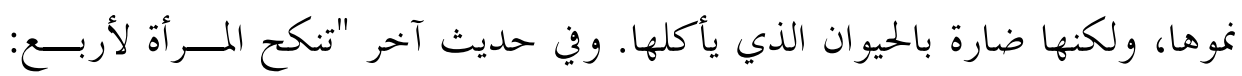

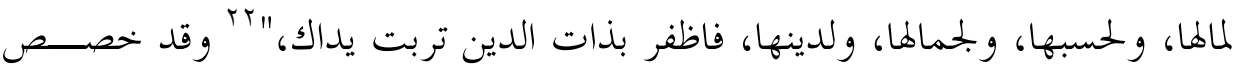

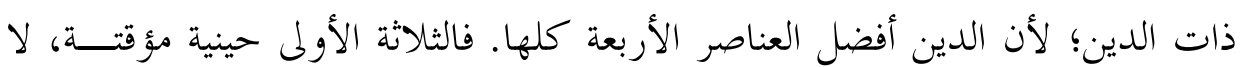

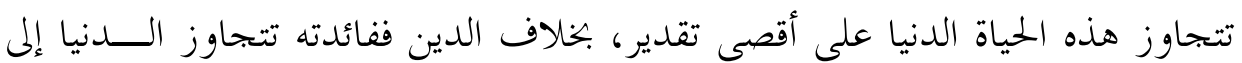

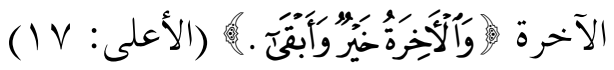

\section{ب. مجالات جمال الكون في القرآن الكريم:}

نعرض لمحالات الجمال في الكون والوجود مما نبصره ونشاهده ونراه، فمن ذلك الجمال في صورة الإنسان؛ إذ يمتن الله، سبحانه وتعالى، على عباده في تحسين صورةهم، وتعديل خلقتهم، وتقويم هيئتهم لاستشراف القيم الجمالية في خلقهم، فيقول: إلََّد

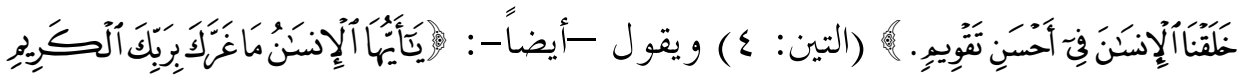

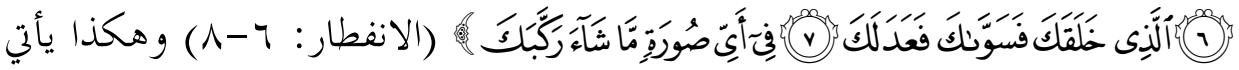

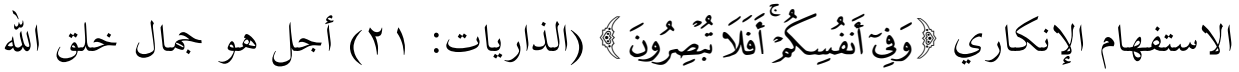
في أكرم مخلوقاته: الإنسان ذلك المخلوق العجيب الذي فيه تتجلى قدرة الخالق في

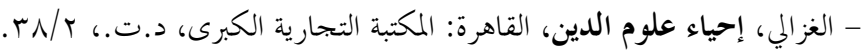

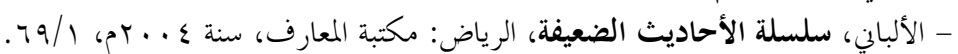

- البخاري، محمد بن إسماعيل. الجامع الصحيح، تركيا وتونس: دار الدعوة ودار سحنون، موسوعة الســنة

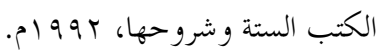
- مسلم، الصحيح، مرجع سابق، كتاب الرضاع، باب استحباب نكاح ذات الدين (0 (1)، رقمبه. 
جمال تركيبه، وحسن هيئه،، وتناسق أعضائه وانسجامها، ذلك التركيب المتر ابط الذي إذا اختل منه جزء -ولو كان صغيرًا - تأثرت به سائر الأجزاء الأخرى.

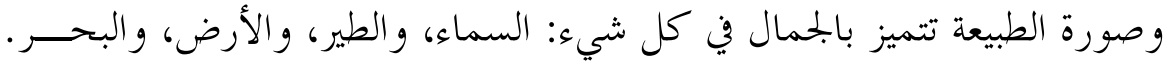

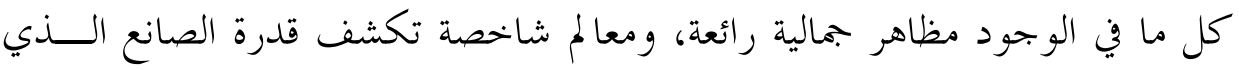

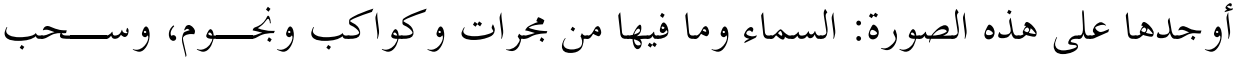

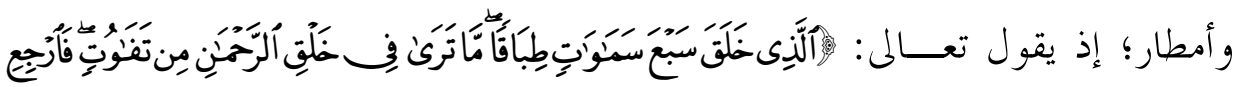

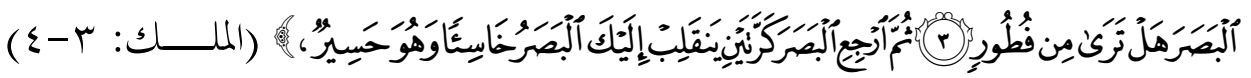

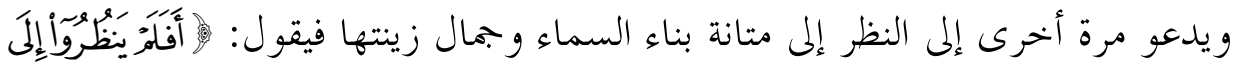

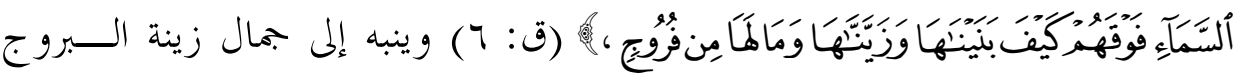

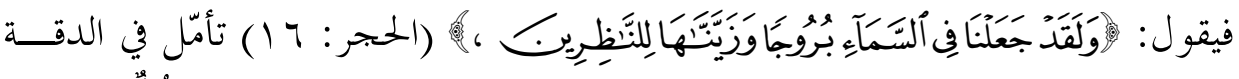

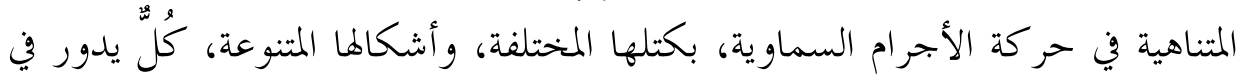

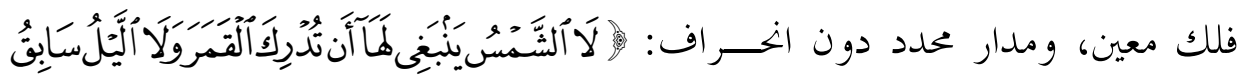

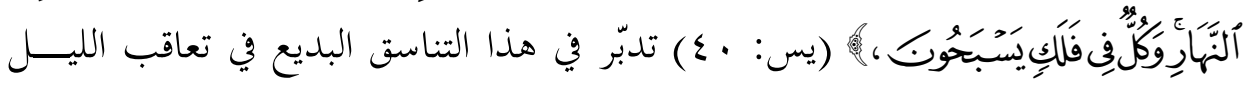

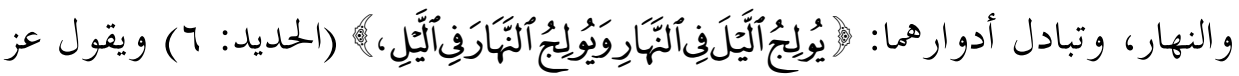

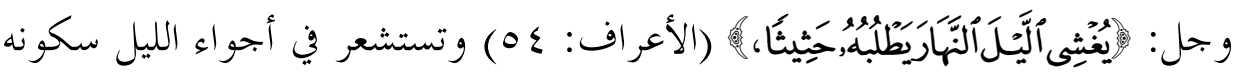

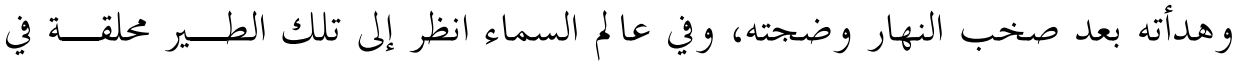

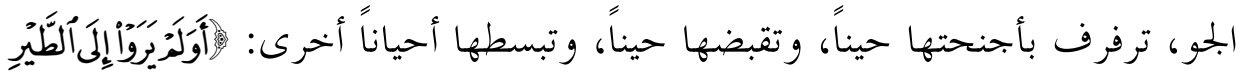

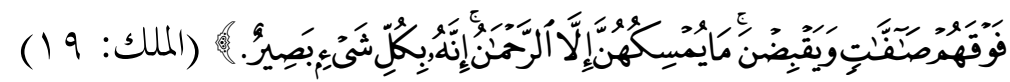

وعالم الأرض وما فيها من جبال ومحيطات وبحار وأهار، وما عليها من إنسان وحيو ان ونبات وجمادات، كلها مظاهر جمالية فنية تشهد بجلال قدرة صانعها المولى عز

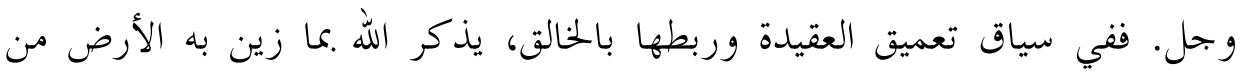

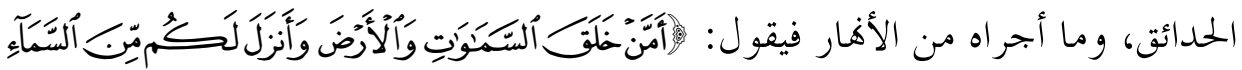

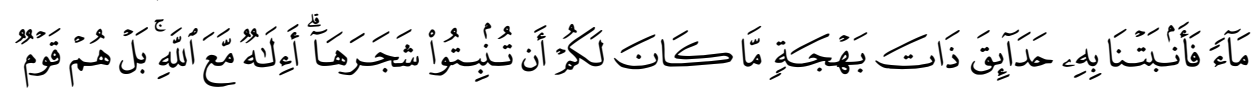

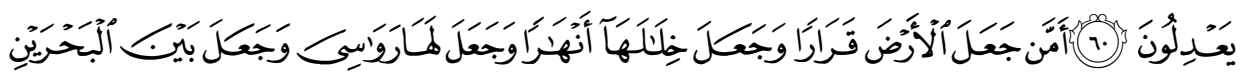




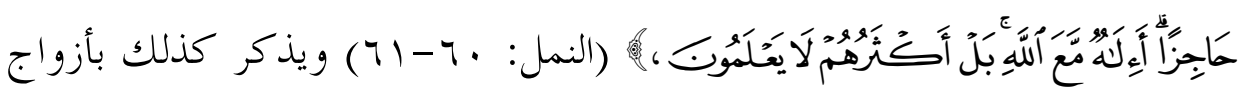

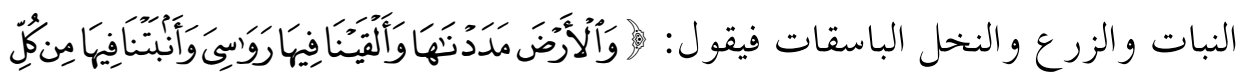

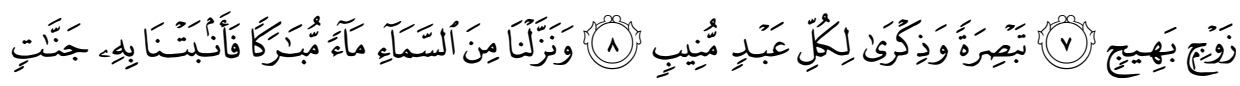

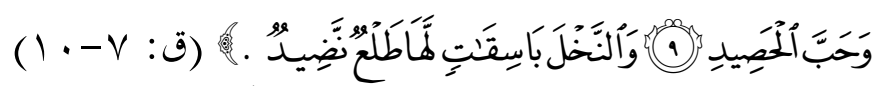

وعلى سطح الأرض بند في النبات الخضرة ذات الثمرات، و ذلك في قوله تعالى:

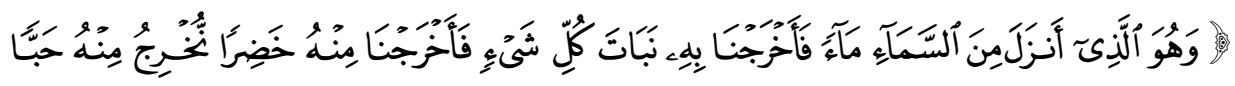

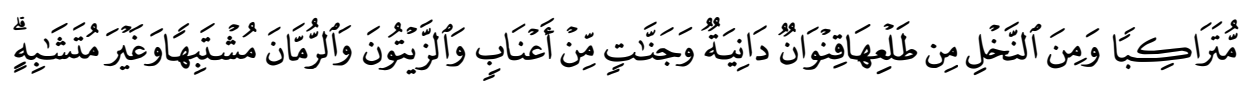

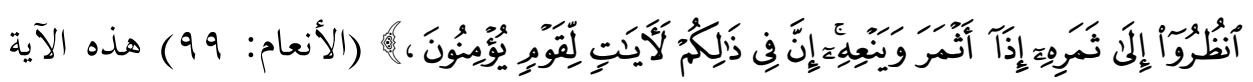
الكريمة -رغم قصرها- لوحة فنية متكاملة بين إنزال الماء من السماء، وإخراج النبتة الخضراء الخلابة في الجمال، فاستقامتها على سوقها، فخروج الحبات المركبة بعضها على بعض، في ألوان مختلفة زاهية، هذه الأنواع من النبات والفواكه: حب و خخل

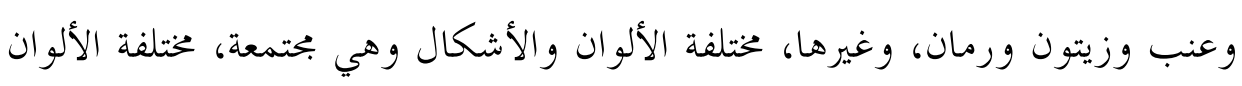
مع تعدد كل نوع منها على حدة: لون حال خروج الثمار جديداً، ولون حال ينعه يتراوح بين أخضر وأصفر وأحمر، وأسود وبين وزيتي اللون، كلها آيات من الله -

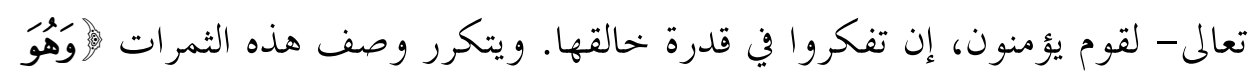

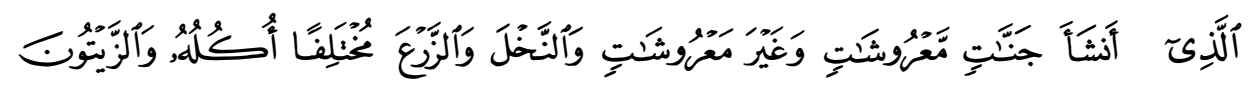

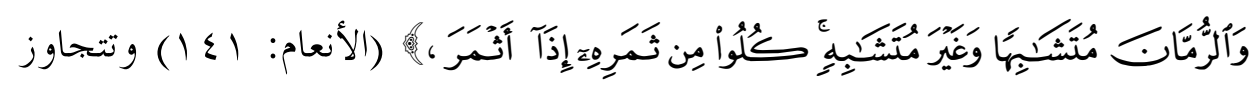

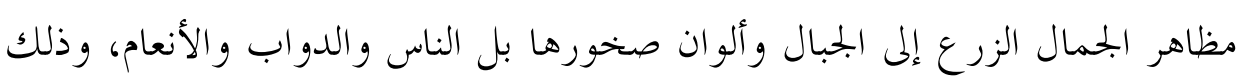

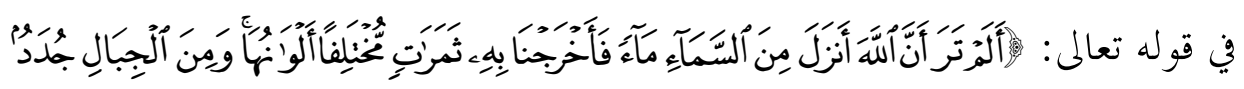

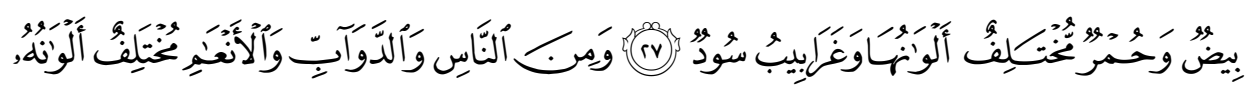

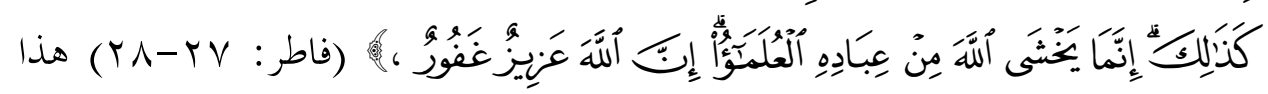
التنوع في الجمال، لاستشعار عظمة الخالق، لذلك كان العلماء أكثرهم خشية لله.

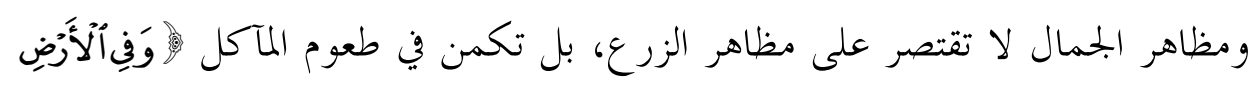




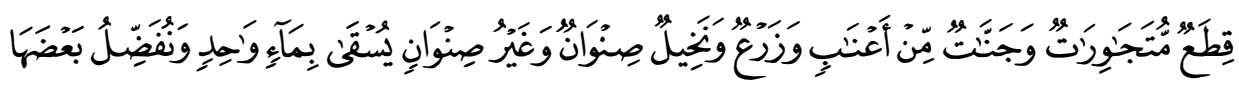

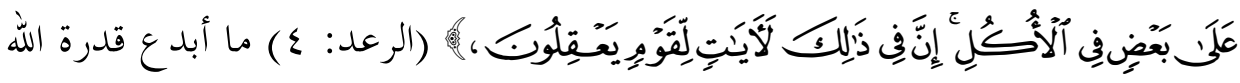

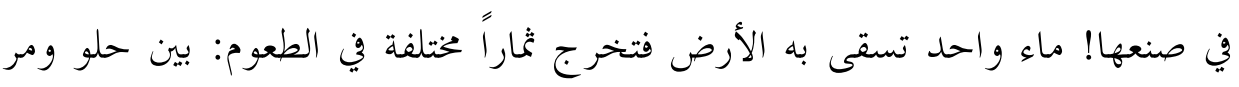
وحامض.

وفوق هذه الأرض مع النبات والزرع والثمار أصناف الأنعام والحيوان، وبتجمع هذه الأصناف في لوحة واحدة ضمن آيات متتابعة في سورة النحل، مع تنبيه القرآن

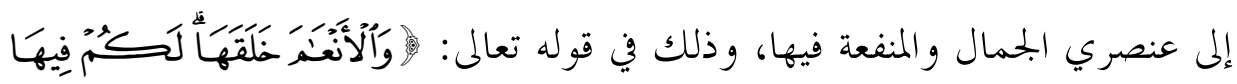

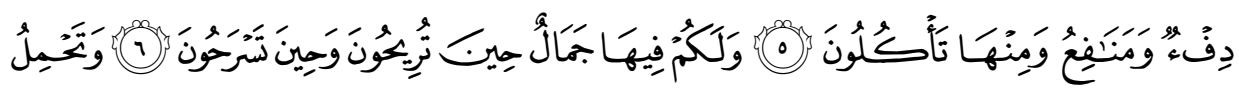

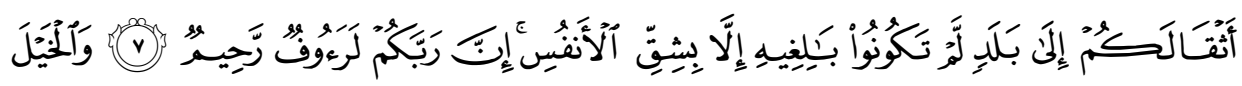

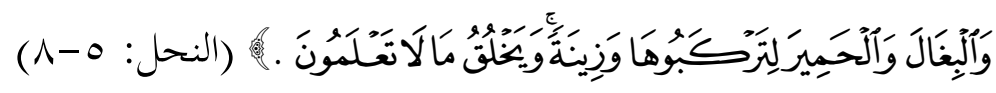

انظر إلى ذلك البحر المتلاطم الأمواج: الجبار حتى لتهابه الجواري العظام، الوضيع

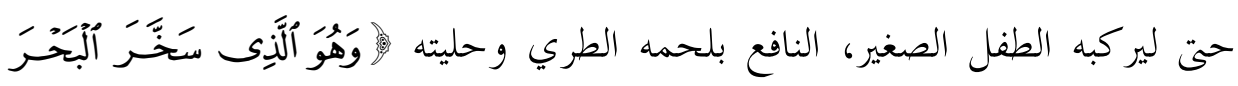

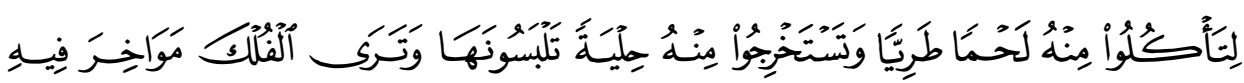

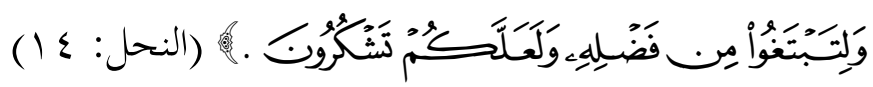
كل هذا الجمال والتنوع في الأرض والزرع، و السماء والطير، والبحر بأمواجـهـ

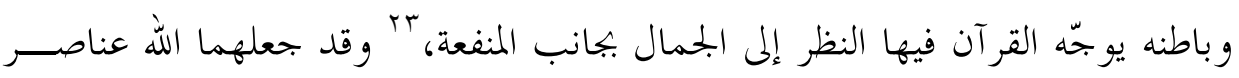

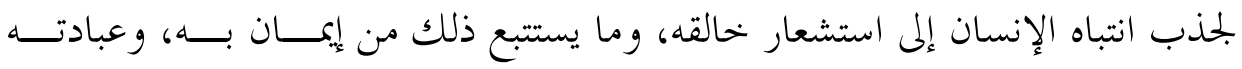

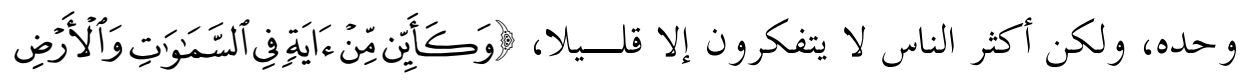

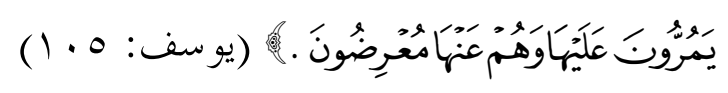

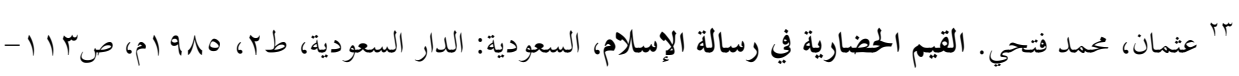

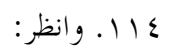
- القرضاوي، يوسف. الإسلام والفن، مرجع سابق، صع ا-17 ا. 


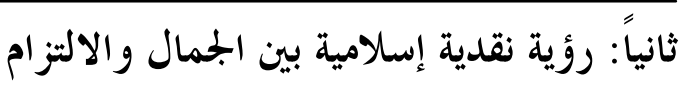

\section{I ـ المسؤولية في القر آن والقو اعد الشرعية:؟}

يقرر الإسلام المسؤولية التي ناطها بالإنسان فيجعلها في بي آدم كلهم، قال تعالى:

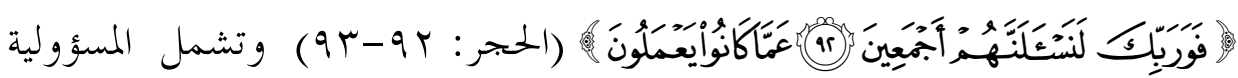

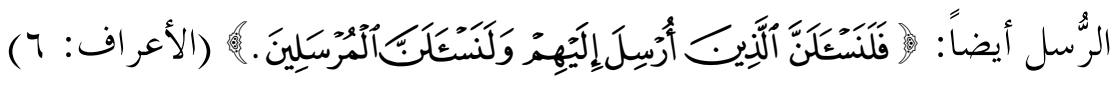

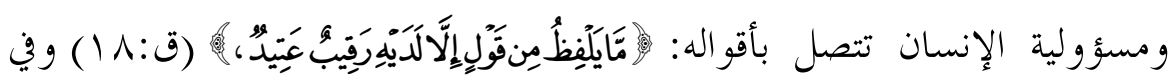

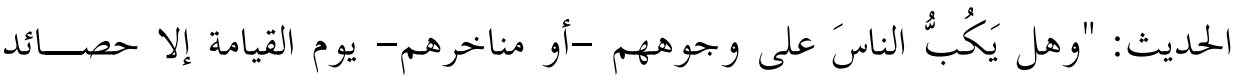

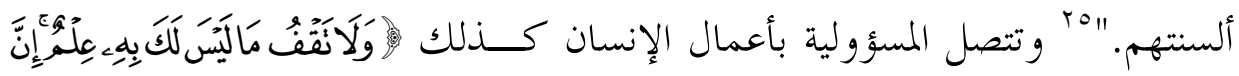

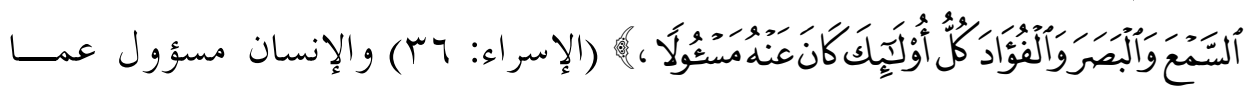

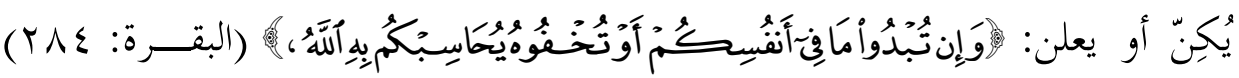

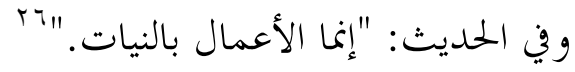

ولكن هل تُضيِق هذه المسؤولية - في العمل و القول سراً وجهراً آ علــى حريـــة

الأديب، وتحول دون قيئة الجو المناسب للإنتاج الفين الرفيع؟

و الحقيقة أن حرية الالتزام في الإسلام تلقائية تنبع من روح الأديب المسلم نفســه،

فو جدانه المؤمن هو الذي يوجه أدبه، وليس في الإسلام تقييد لحرية الأديب، بل يبقـى الميدان له رحباً فسيحاً يجول فيه بمرونة وحرية، و المسؤولية مستمدة من أصول الإسلام وقو اعده؛ و ذلك للأسباب الآتية:

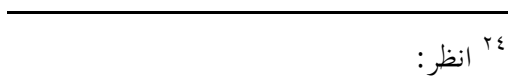

- ناعسة، حسني. شعر الفقهاء نشأته وتطوره، رسالة ماجستير بآداب جامعة القاهرة سنةع ول ام، ص.. و وما بعدها.

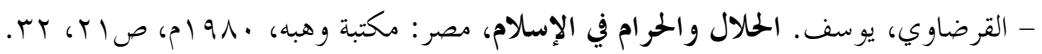

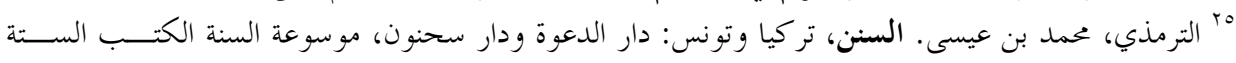

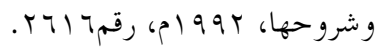

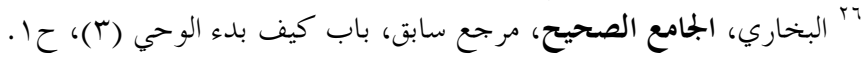




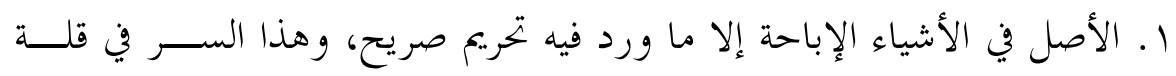

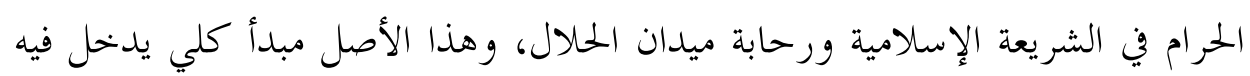

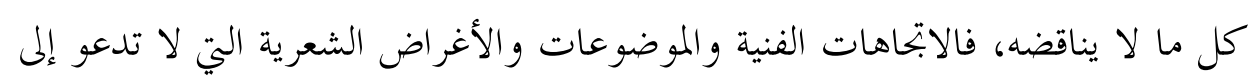

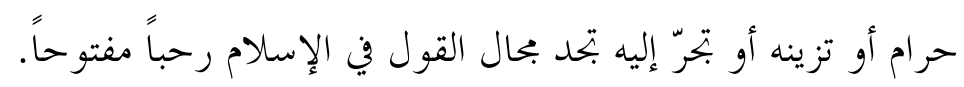

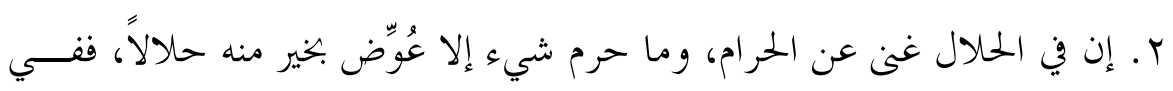

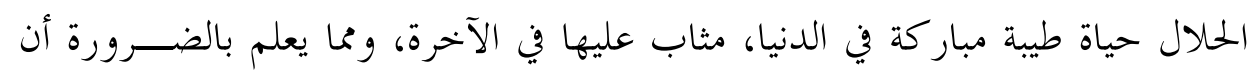

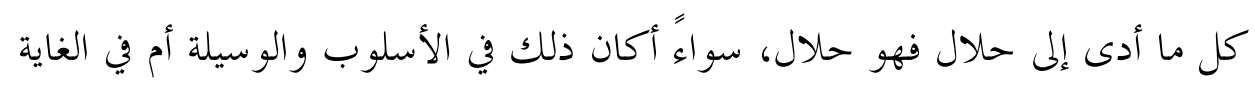

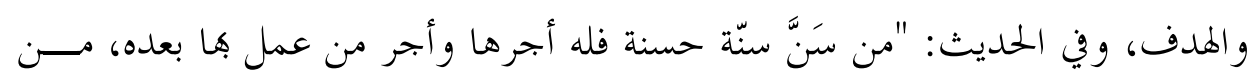

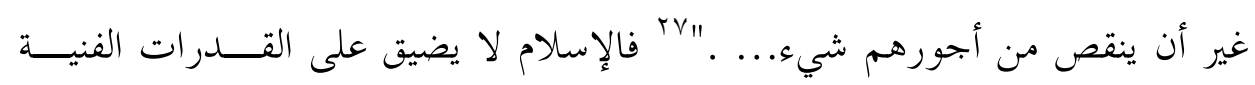

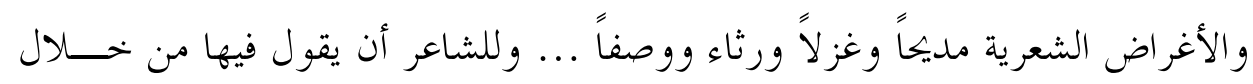
التصور الإسلامي دون حرج أو تردد.

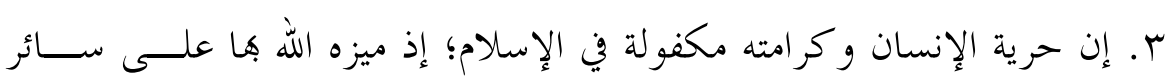

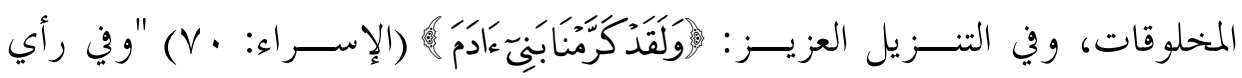

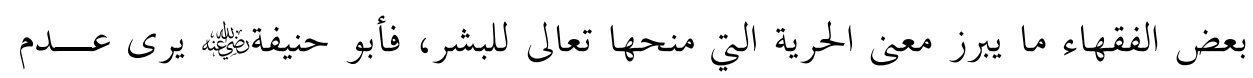

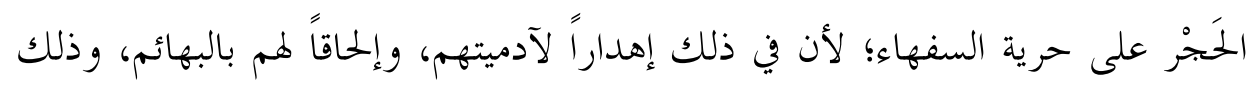

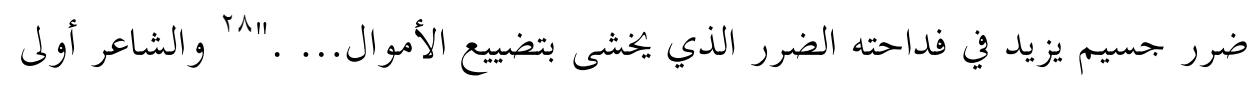

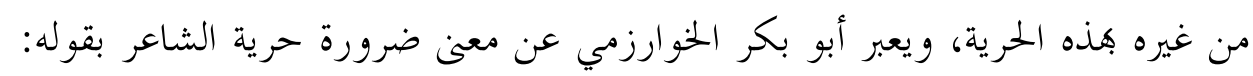

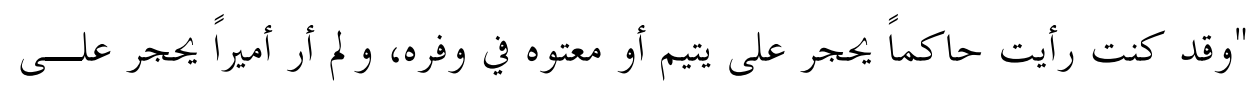

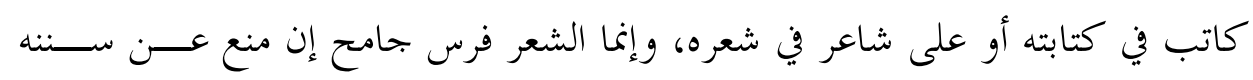

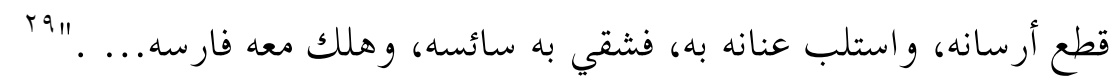

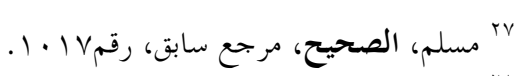

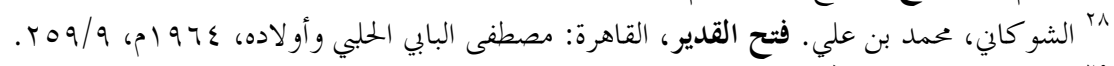

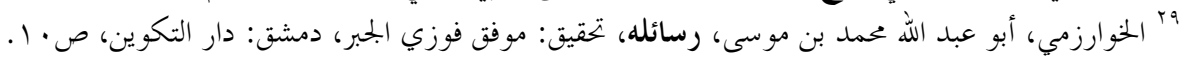


ع. إن الإسلام يدعو إلى ريادة الآفاق، و الاهتداء إلى الطرق الجحديدة، ويؤازر هذه السبل ويباركها وينصرها على نوازع الشر وعناصر الضعف، كما يهتــف بـــالقوى المتسامية وقدرات الارتقاء إلى السمو والرقي وبلوغ معالي الأمور، ففي الحديث: "إن

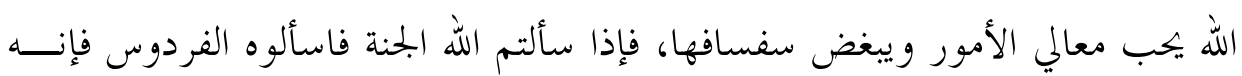

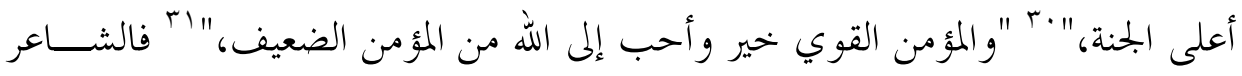
الإسلامي لا ضيق في أفقه، بل ينظر إلى بعيد، وينأى عن الأهواء الهابطة.

فالأصول و القواعد الإسلامية دعائم ثابتة بتحاه الفنون الجميلة عامة في تقدير جمال الكون، وأن حبه و التفكير فيه من الفطرة، على أن يكون متوازناً، بَّ وهي - كذلكللالتزام في الشعر لأنه هادف، وليس بالعبث أن يتخذ الشاعر حريته من شريعته، وينبع التزامه من ذات نفسه وأعماقه، حيث يؤمن بالإسلام و يدعو إليه ويدافع عنه.

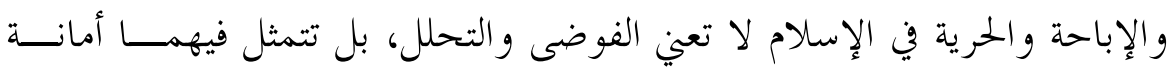

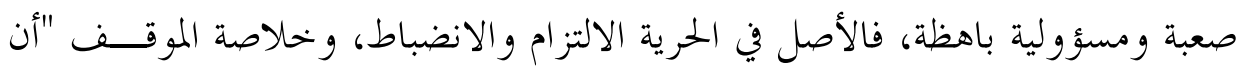
للحرية في الأدب حرمتها وقداستها بحيث يُعدُّ أي عدو ان عليها عدو اناً على الإنسانية، لكن بشرط أن يتحرر مفهوم الحرية، فلا يختلط بالتحلل والابتذال، ولا يلتبس بالإباحة

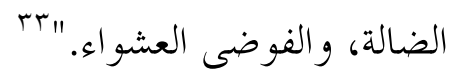

فكرة الالتزام -بدلالتها ومضموفا- قديمة، و إن كانت نشأقةا الحقيقيــة نتيجـــة

للإحساس بقيمة الأدب والاعتراف بعمق تأثيره وتوجيهه في العصر الحديث، ولعـل

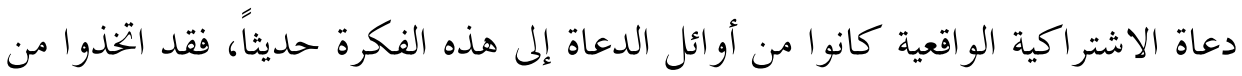

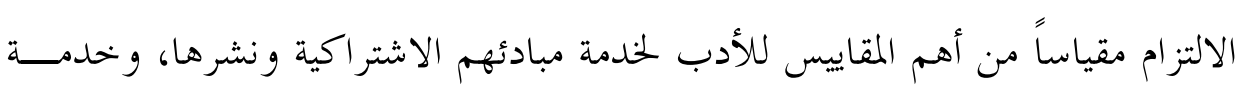

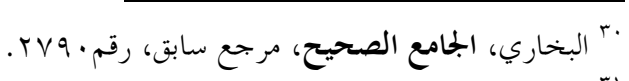

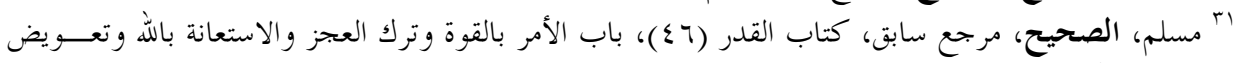

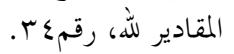
rr

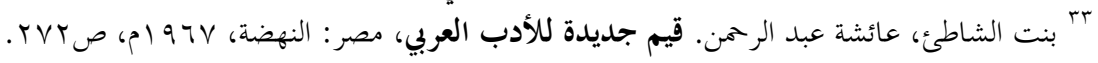




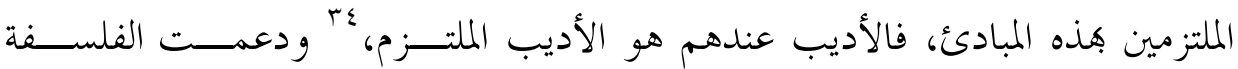

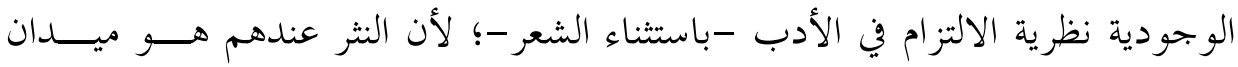

و الأديب الملتزم ليس مطالباً أن يكون -فقط- مر آة بحتمعه، بل مساهماً في تكييف هذا البحتمع وتوجيهه و الذود عنه، فهو جزء لا يتجزأ منه، يشاركه في آماله و آلامــه،

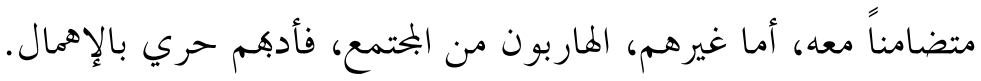

و يعارض البعض هذا المقياس بدعوى أن الأدب ليس غاية يتغذى بموقف يعارض

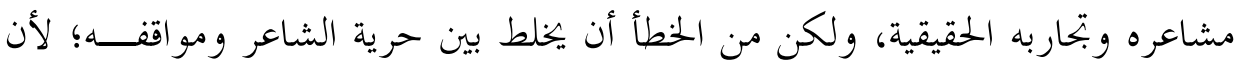
تعبيره قد تتطلبه حريته نفسها. و كذلك فمن الخطأ أن يخلط بين صدور الشاعر عــن بحتمعه، و التزامه؛ فالأدب يصور حياة شعو به، وإنما الذي يختلف فيه أن يكون الأديب ملتزماً بقضايا معينة ومبادئ خاصة، ويصارع من أجلها، كقضية البؤس مثلاً، فالحياة

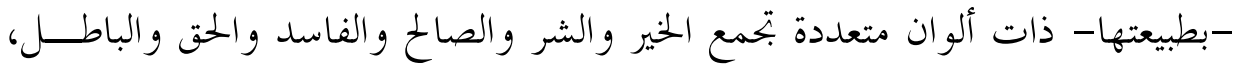
فالأرجح أن يكون الالتزام بالحق والخير والنفع؛ لأنه الوجه الفعال في الحياة الإنسانية. ومن التعسف أن يلتزم الأديب التزام العالم أو صاحب المـــذهب السياســي؛ لأن

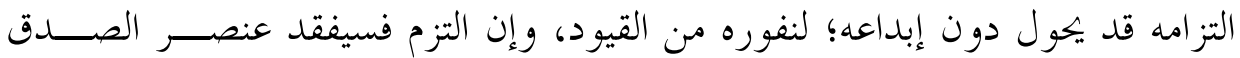
الفين. وقصة الكاتب الروسي (فلاديمير ماياكوفسكي) كاتب الثورة الروسية وشاعرها تبطل دعوى الالتزام الضيقة، فقد خحاض معركته الفنية تحت شعار الواقعية الاشتراكية

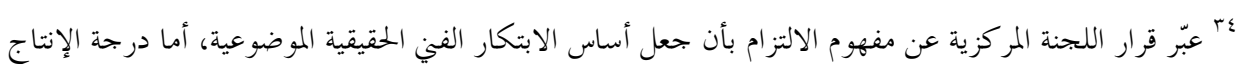

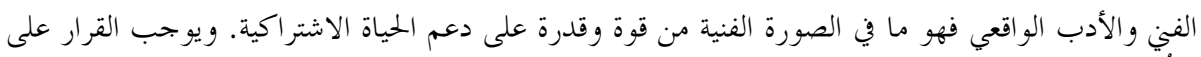

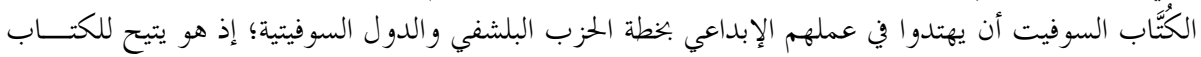

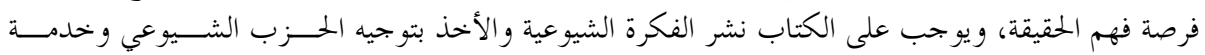

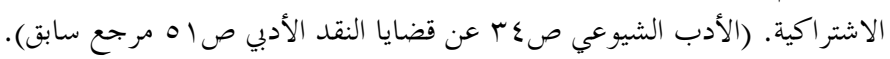

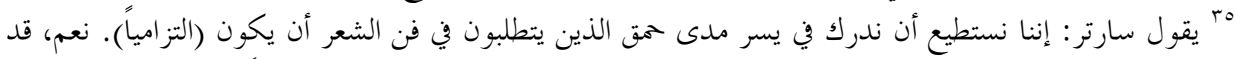

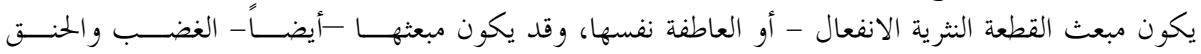

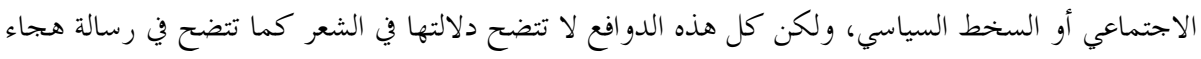

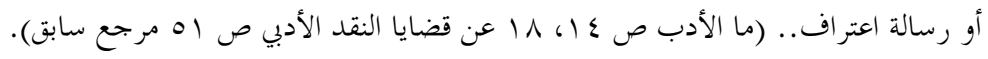


حتى بلغ أقصى الشوط، ثم ساوره الشك في دعوته فانتحر سنة . بو ام؛ ليتخلص من

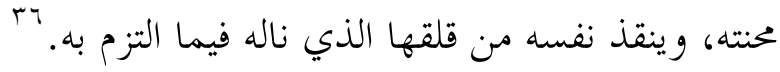

لكن الأدب، عند فريق آخر، جمالي يقوم هدفه وو سيلته على الإجادة و الإبـــداع

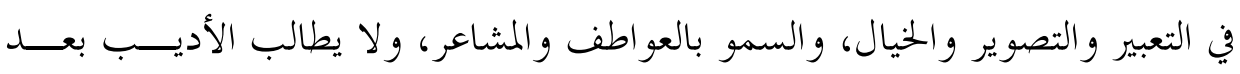

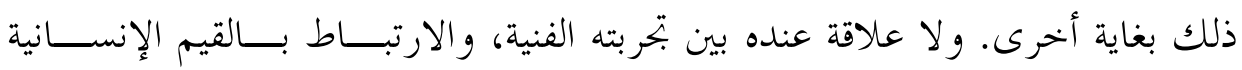
والاجتماعية، وإن أحسن وصف تجربته الشعورية فقد حقق الغاية والهدف.

وقضية الالتزام تقع بين مذهبين: الفن للمجتمع (الحياة)، و الفن للفــن، و الـــــي يُحذَر منه في الاتجاه الأول أن يتحول الأدب إلى وعظ و خطابة مباشرة، ويفقد عنصر الإثارة والحيوية، وإن كان نبيلاً صالحاً في هدفه، كما يُحذَرَ في الاتجاه الآخر أن يتجرد

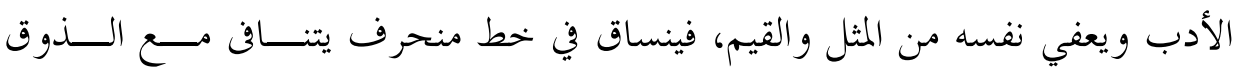
السليم، و يتلبس بالفحش و الفساد و الضلال.

و الفنان في الحقيقة واقعي ومثالي في آن واحد، وبهما يتحقق الالتزام وليس الإلزام؛ لأن الأخير خحال من الحرية والمتعة والتشويق، و لا يحقق لذلك هدفه المطلوب، وهو ما آل إليه الأدب الشيوعي، تقول بنت الشاطئ: "واشتدت الرقابة في عهــــ (ســتالين) فرفضت كل من لا يخضع لهذا الإلزام.... ولكن التجربة كشفت عن خطأ هذا الإلزام و خطره، فجاءت الأعمال الفنية مختنة بأغلال القيود، وأعوزةقا حرارة الإيمان، وصدق

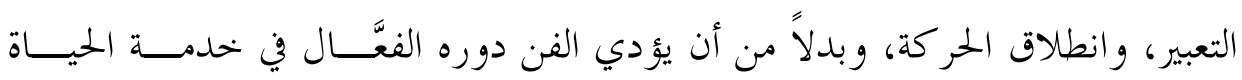
وقيادها، انفصل عنها وصار مجرد أداة تعليمية للدعاية المباشرة."

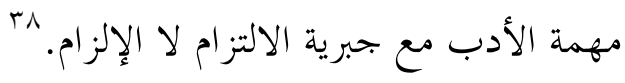

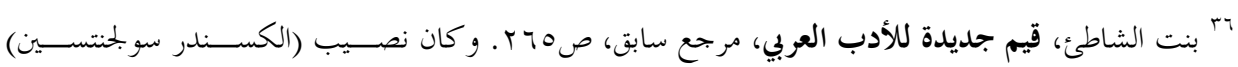

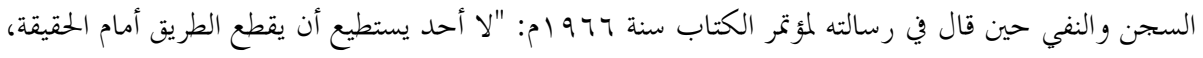

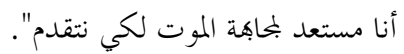

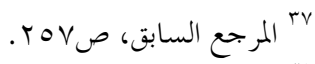

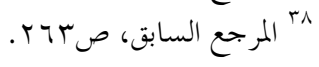




\section{r ـ الجمال بين الذاتية والموضوعية:}

اختلف الفلاسفة والأدباء و النقاد في ذاتية الجممال وموضوعيته وتباينت آراؤهـــم:

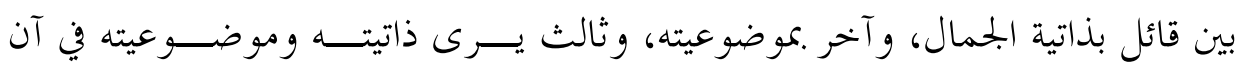
واحد.

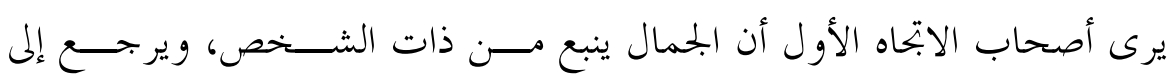
الظروف النفسية التي تحيط بالإنسان، وينكرون أن تكون هناك معايير موضعية مستقلة عن رد الفعل من الشخص: "وذلك لأن الأشياء التي تبدو جميلة في نظر بعض النـــاس،

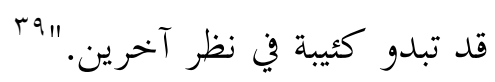

ولو كان للأشياء جمال موضوعي لما اختلف اثنان في جمال الشيء ومقدار ذلـــك

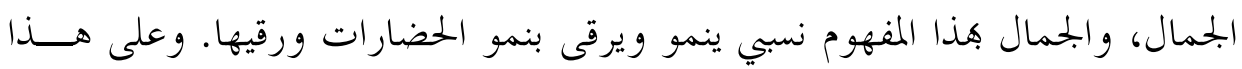

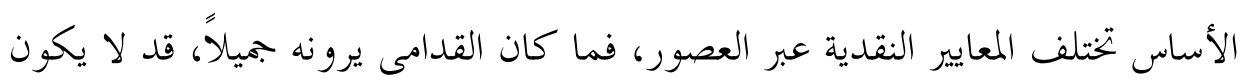

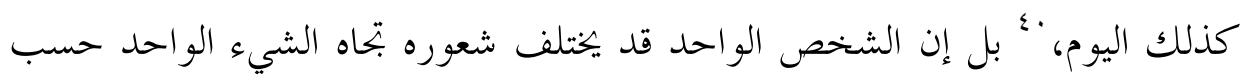

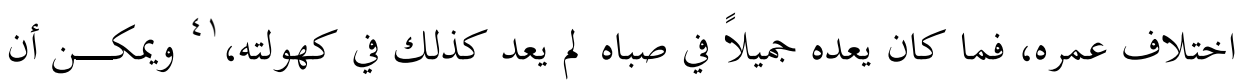
نضرب مثلاً في بيان ذاتية الجمال باللون الأحمر بين شخصين، فقد يراه أهماه أحدهما جميلاً

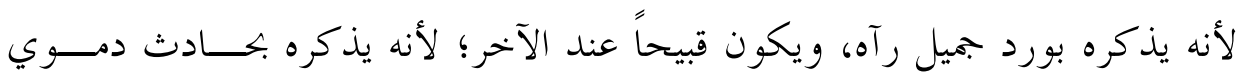

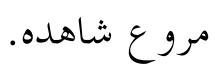

ويذهب أصحاب الابتحاه الآخر إلى أن سر الجمال إنما يرجع إلى روعة الشـيء في نفسه، فالطبيعة تقدم لنا نماذج من الجمال، كما نرى في الورد، وي مناظر أخرى: في

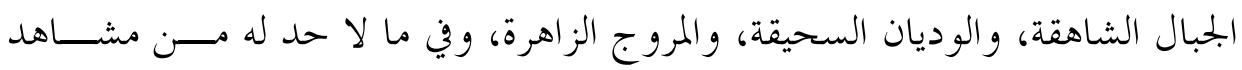
أخرى. أنبا.

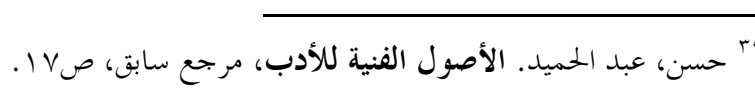

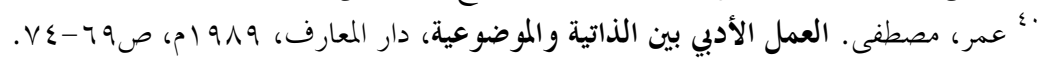

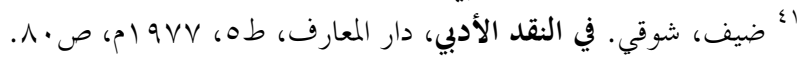

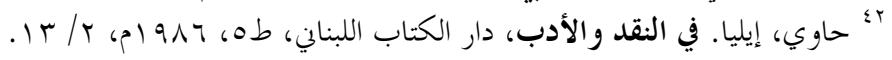


وإذا سلمنا بجمال الأشياء المذكورة، بقي أن نسأل: ما الذي جعلها جميلة وغيرها

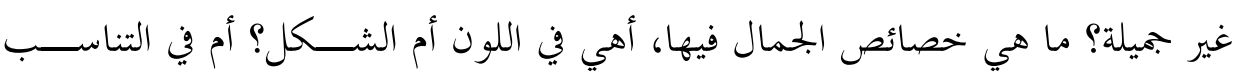
و التناسق والانسجام؟ أم في التوازن بين أجزائها؟ أم في شيء آخر؟ يرجع أصحاب هذا فئا الاتحاه سر الجمال في الطبيعة والفنون إلى التناسق والتناسب و التوازن بين أجزاء الشيء وعلاقاتها. "ففي الجميل ضرب من توافق النظام هو سر جماله، وهو يبدو في تناســبـ

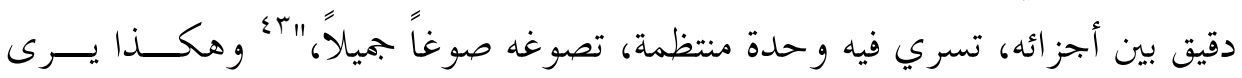

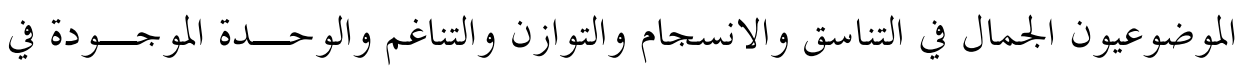
الأشياء، سواء في المرئي منها أو المسمو ع أو أو غير هما.

و حاول الفريق الثالث التوفيق بين الرأيين السابقين: فلم يقولوا بالذاتية المطلقة ولا الموضوعية المطلقة، ومن أصحاب هذا الرأي شوقي ضيف الذي يرى أن "الجمال ذاتي

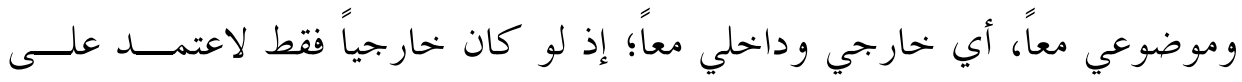

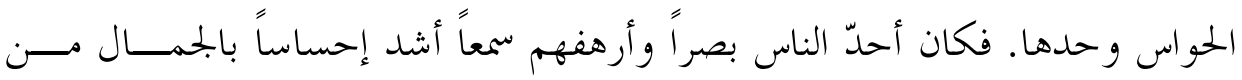

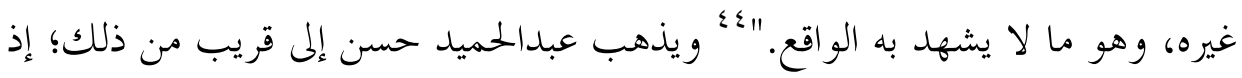

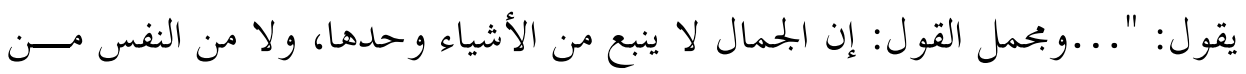
غير مؤثرات مباشرة وغير مباشرة. "هو

و نستخلص من هذا أن الجممال من الناحية الذاتية هو ذلك الانطباع الذي تمتلكـــــ

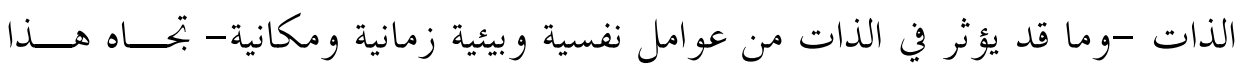
الشيء الجميل، أما من الناحية الموضوعية، فيمكن ملاحظة الجمال في التناسق والتوازن و الانسجام الذي يتجلى في المظاهر، والأصوات وغيرهما من الأشياء، وهذا الموقف هو الأقرب إلى رأي الإسلام الذي سيأتي بعد قليل. و الإمام أبو حامد الغزالي يرى الجمال ذاتياً وهو يتحدث عن الجمال في الأشــياء

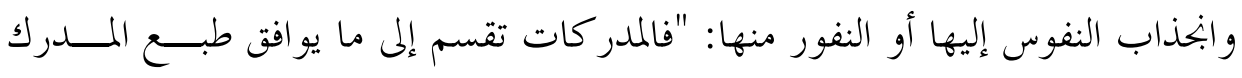
ك" ضيف، شوقي. في النقد لأدبي، مرجع سابق، ص • م.

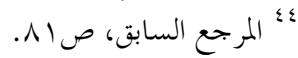
0؛ حسن، عبد الحميد. الأصول الفنية للأدب، مرجع سابق، صو 1 . 


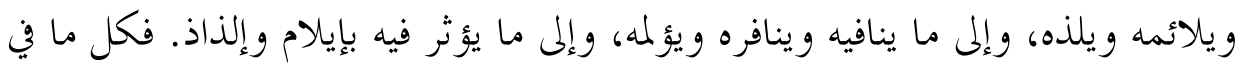

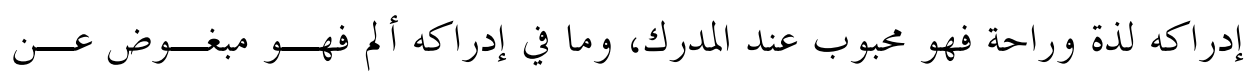

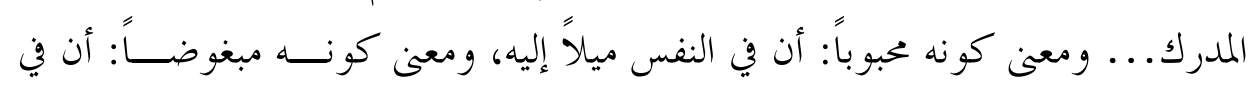

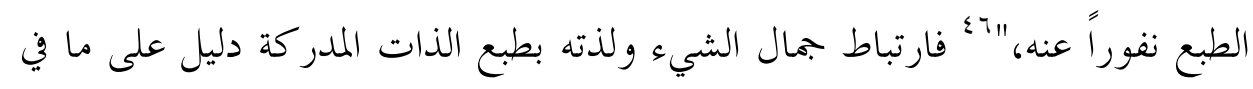
إدر اكه المتعة والجمال من ذاتية.

وفي موضع آخر يصرح الإمام الغز الي بموضوعية الجمــال، واخــتلاف معــايير

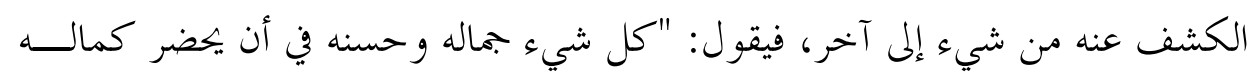

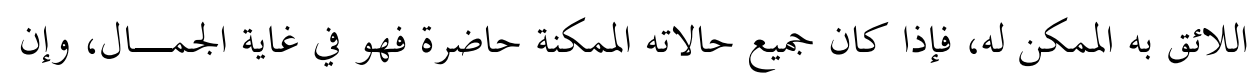

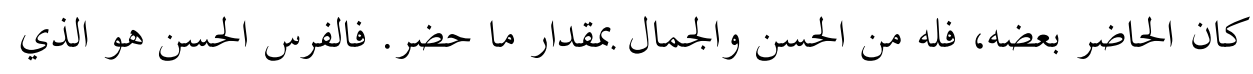

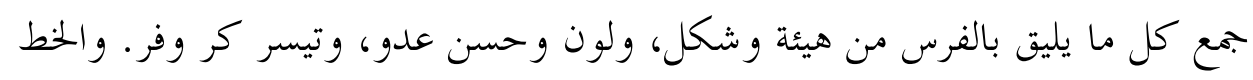

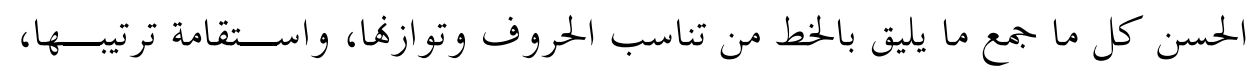

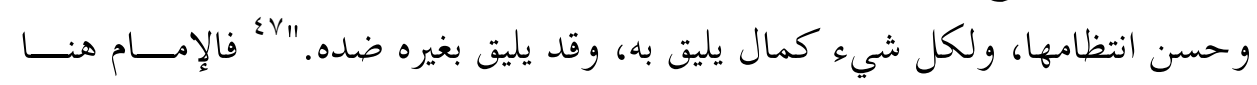

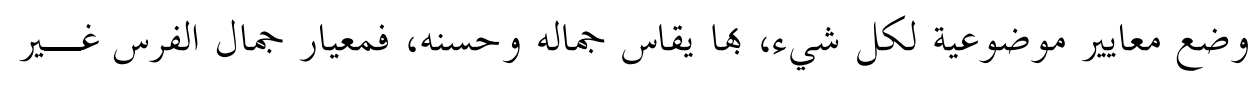

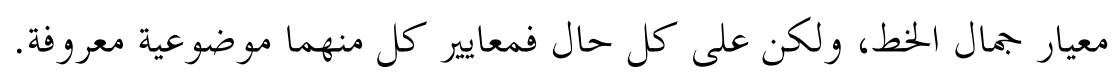

وأبو حيان التوحيدي بيّن العناصر التي تتدخل في الحكمم على الشيء بالجمـــال أو

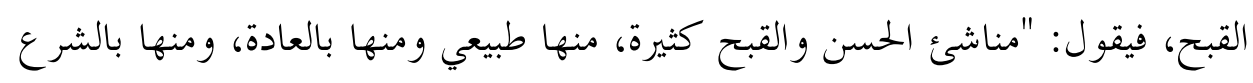

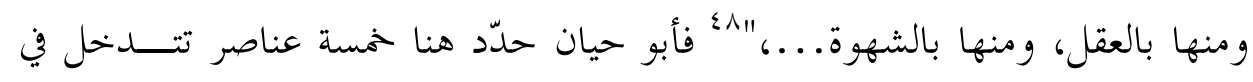
تحديد الشيء الجميل: العنصر الطبيعي، و العنصر الاجتماعي (العادة)، والعنصر الديني،

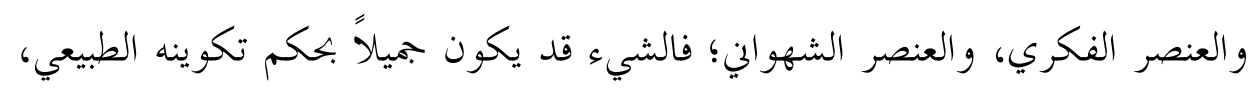

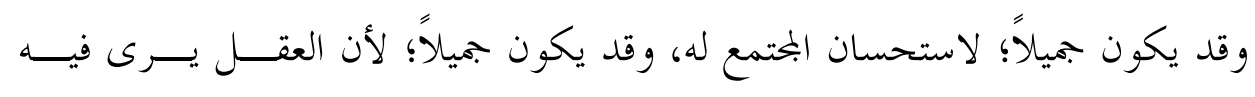

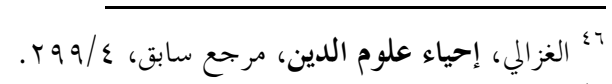

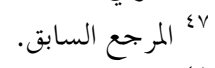

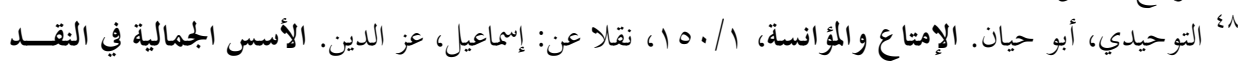

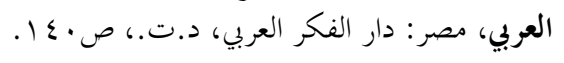




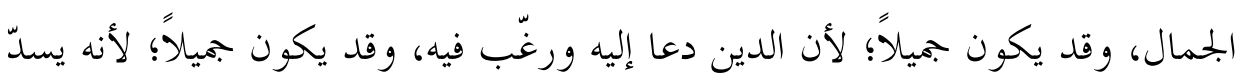

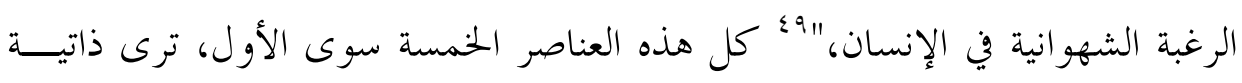

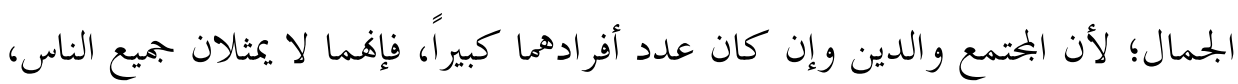

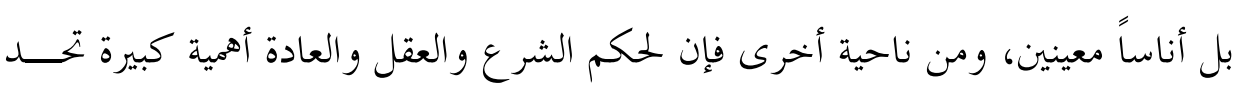
من أثر الطبيعة والشهوة، وتضيق عليهما.

وخلاصة القول: إنَّ الجمال ليس ذاتياً مطلقاً، وليس موضوعياً مطلقاً، وإنما فيــــ جو انب بجرّه إلى الذاتية، وأخرى تقرّبه إلى الموضوعية.

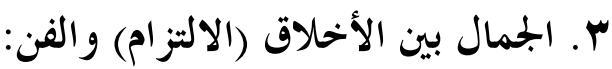

الدين الإسلامي دين مبني على أساس أخلاقي رفيع، فقد قالط مكارم الأخلاق،" ·ه فكل تصرف من الفرد ضد هذا المبدأ يعد خرقاً صارخاً لمبادئ

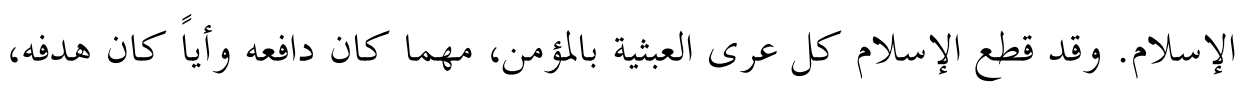

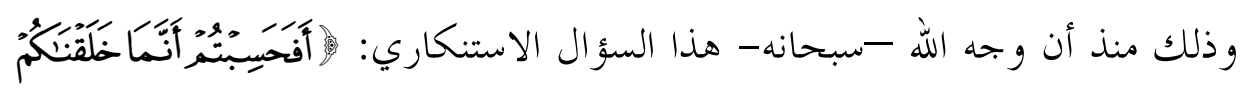

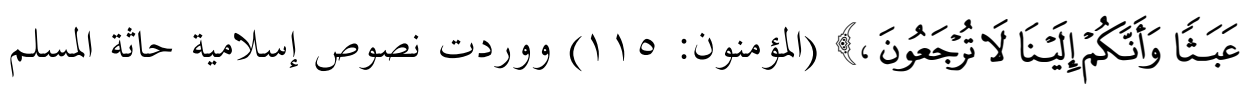

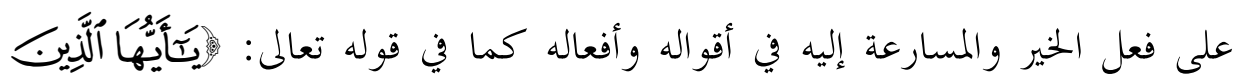

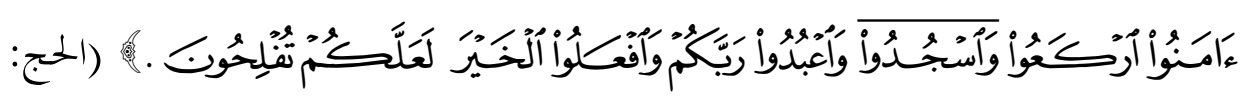

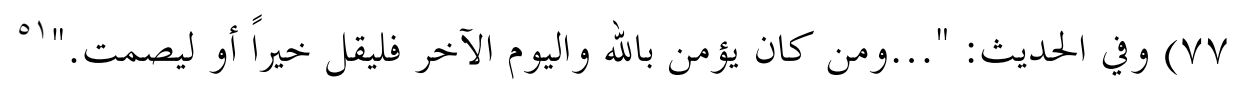

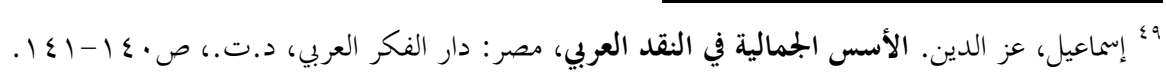
أنظر

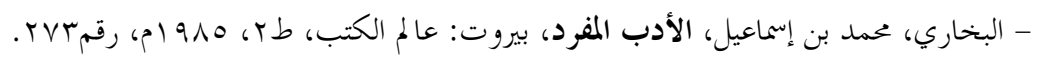

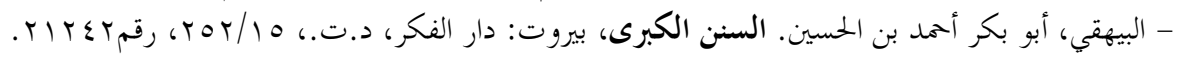

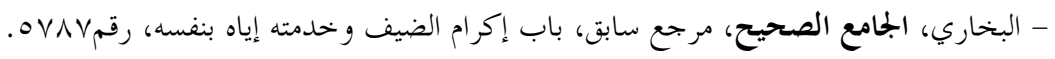

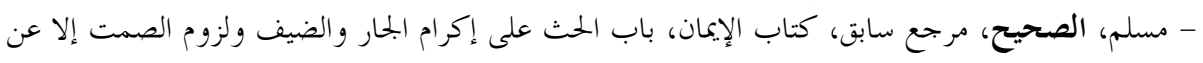
الخير، وكون ذلك كله من الإيمان (19)، رقمعابل الرمان. 
و بعد ذكر آراء النقاد السابقين في الذاتية و الموضوعية بجد طائفـــة مـــن النقـــاد

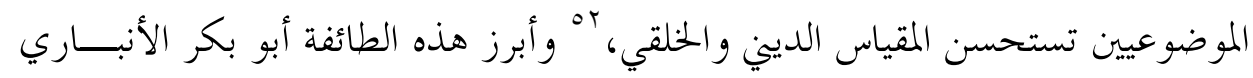

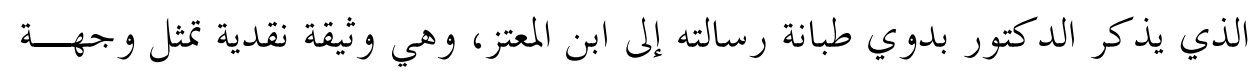
نظر دعاة الالتزام الخلقي من النقاد العرب من أهل الحفاظ على سلامة العقيدة ومكارم

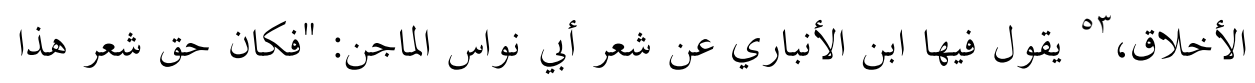

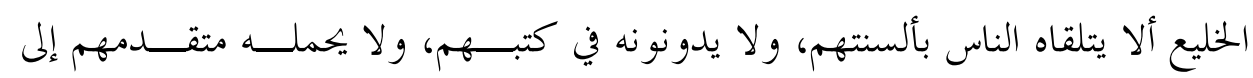

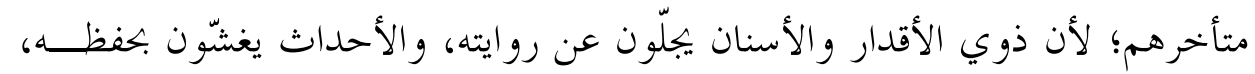

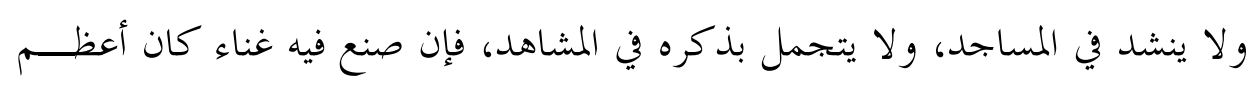

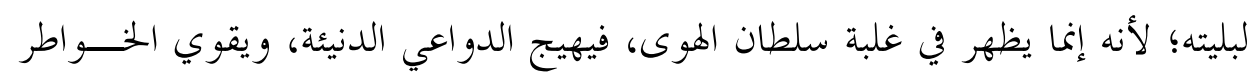

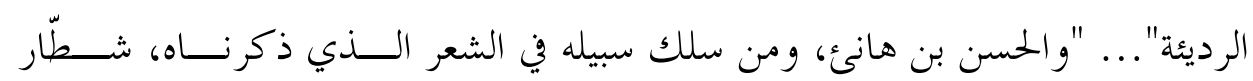

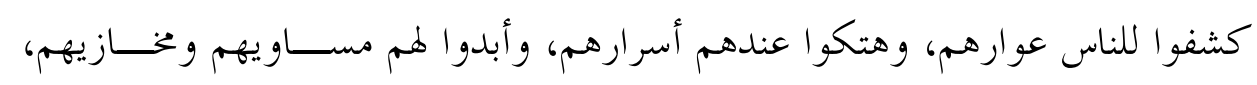

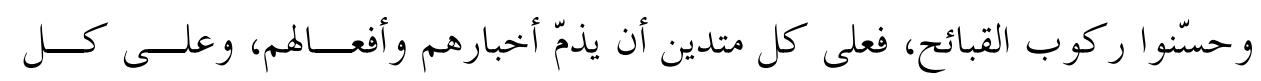

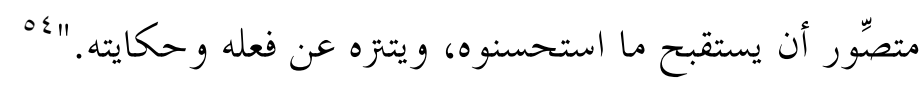

ثم يوازن الأنباري بين ما قاله أبو نو اس وأبو العتاهية مستحسناً ما قاله الأخــير.

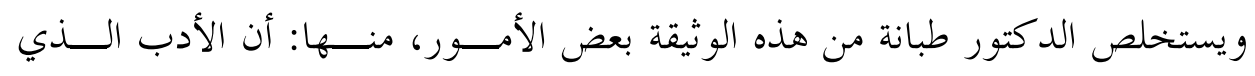

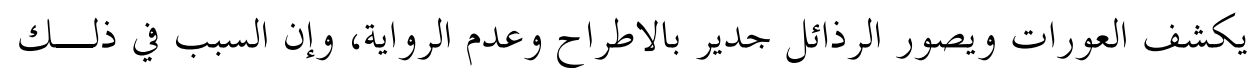

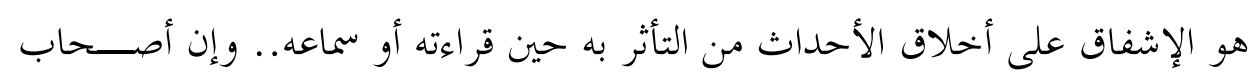
هذا الأدب الفاسد يجب أن تذم أخبارهم و أفعالهم.

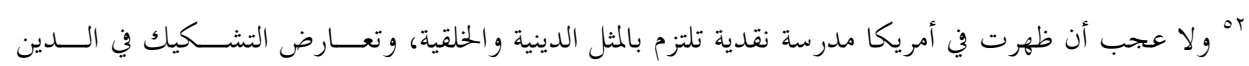

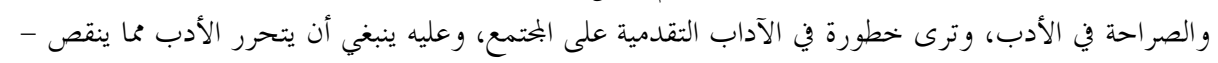

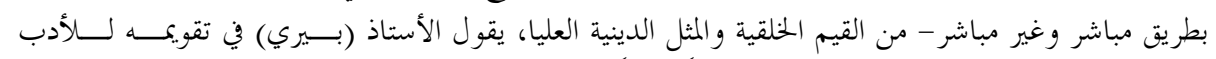

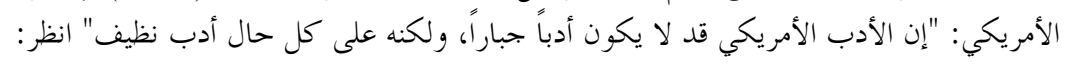

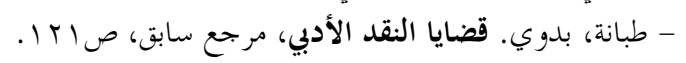

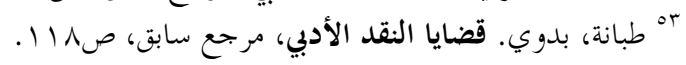

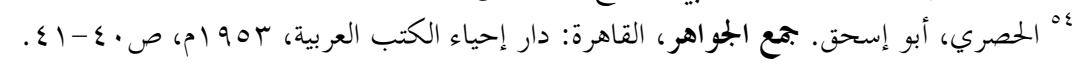

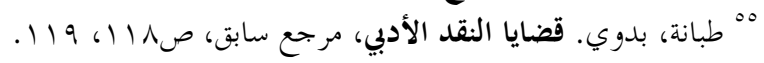




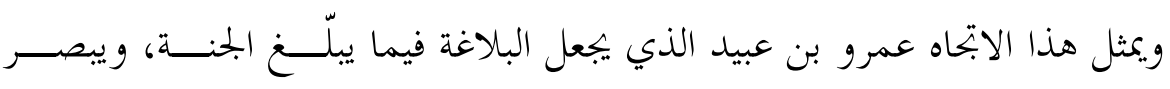

بالرشد والغي، وفي حسن القول بعد حسن الصمت وحسن الاستماع، وفي قلة الكان الكلام

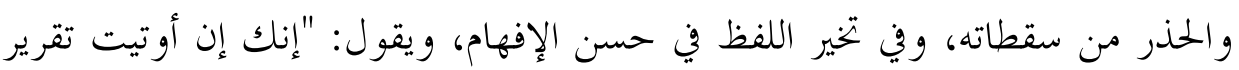

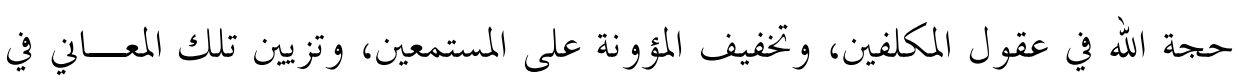

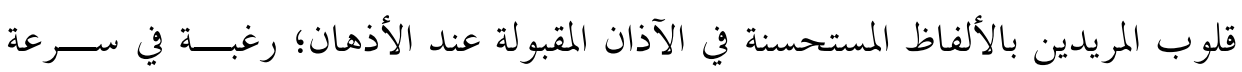

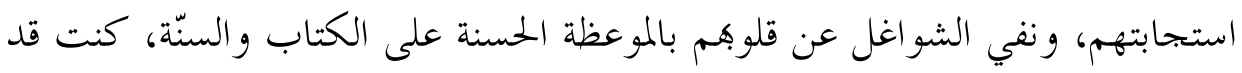

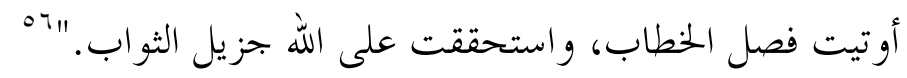

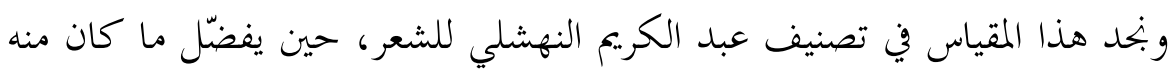

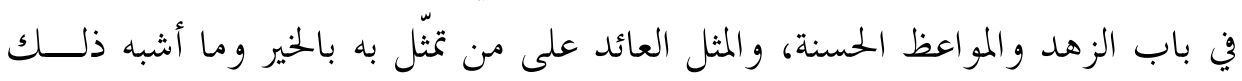

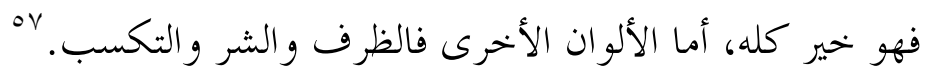

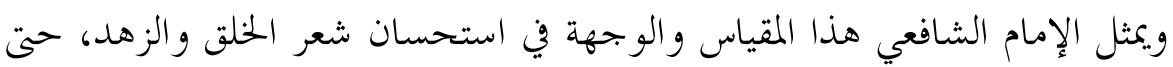

أنه أفتى بجواز الزواج على بيت من الشعر، ولكن إذا كان البيت مثل قول أبي الدرداء:

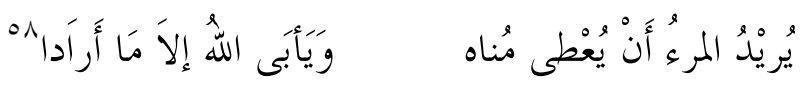

كل هذه النصوص الإسلامية بتعلنا لا نو افق بعض النقاد المســـلمين القـــدماء في

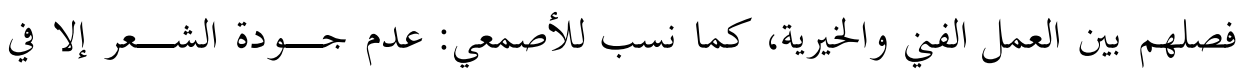

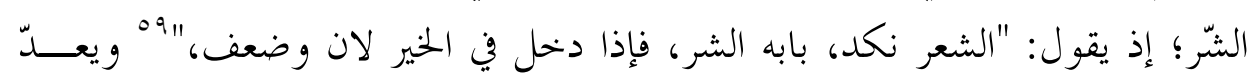
الأصمعي هذا الكلام من أو ائل من نادوا بالتفريق بين القيم الفنية والمثل الأخلاقية.

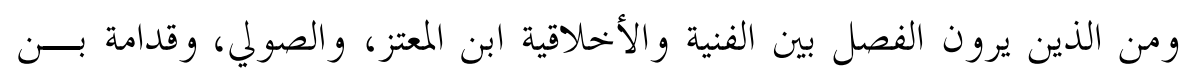

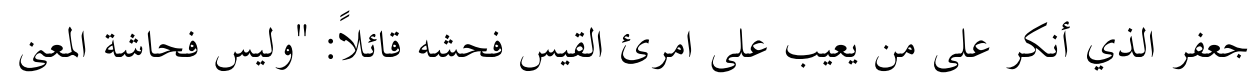

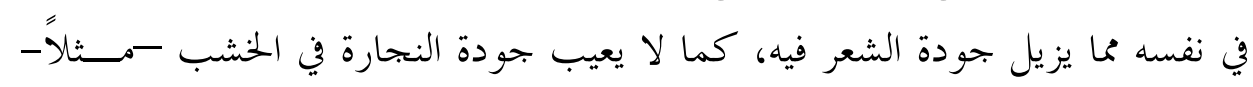

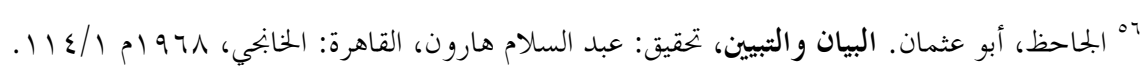

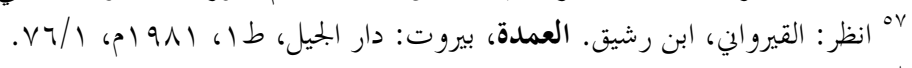

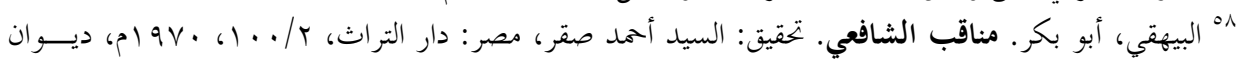

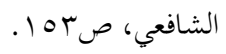

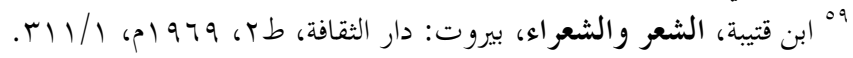




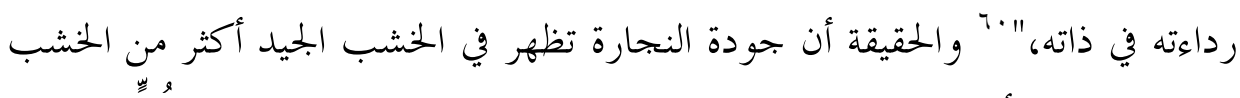

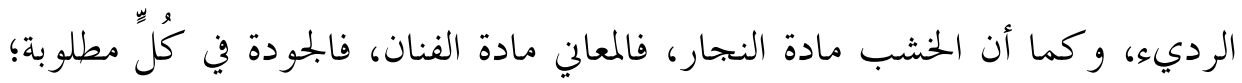
ليجود الفن.

ودعا القاضي الجرجاني - كذلك- إلى تجريد العمل الفني من أي قيمة خلقيـــة أو

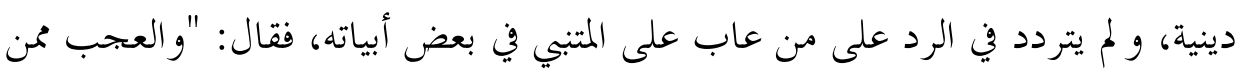

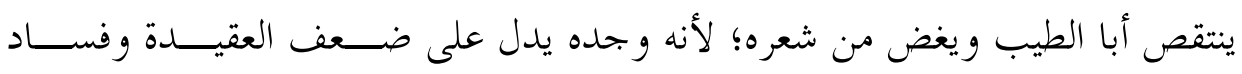

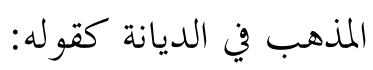

$$
\text { يترشفن من فمي رشفات }
$$

و القاضي الجرجاني لا يرى حرجاً هنا في التلاعب بالمصطلحات الإسلامية، وعدم احترامها، حتى التوحيد الذي عليه تنبي الديانة الإسلامية، وليس له مسوغ غي ذلـــك سوى أن أبا الطيب أجاد في الصياغة اللفظية وأمتع، وما أعجب هذا المعيار الفني! ثم يعلن الجرجاني حكمه الصريح في هذه المسألة قائلاً: فلو كانت الديانـــة عـــاراً

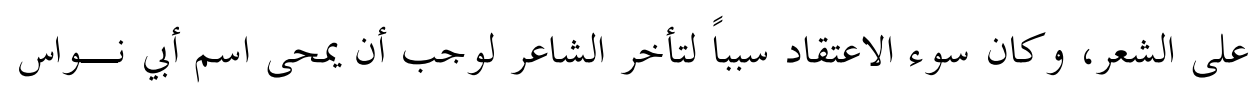
من الدو اوين، ويحذف ذكره إذا عدّت الطبقات، ولكان أولى لهم بذلك أهل الجحاهليــة

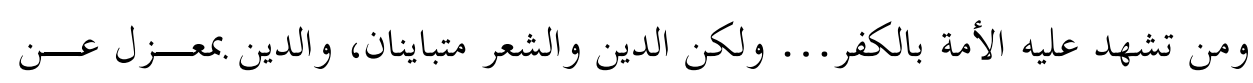

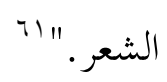

وقد زعم كثير من النقاد أن الفن عملية خيالية وعاطفية بحتة تقترب إلى الجــــودة و الكمال كلما أوغل في المبالغة والخيال، و يقل شأها كلما كان حظ المبالغة و التــــويل فيه قليلاً، و ينسب لقدامة بن جعفر قوله: "ولا يستحسن السرف و الكذب والإحالة في

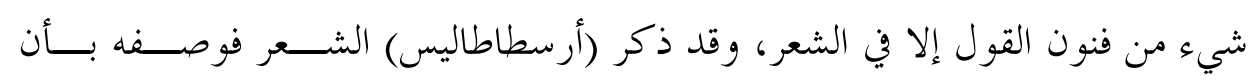

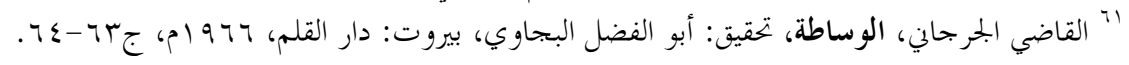


الكذب فيه أكثر من الصدق، وذكر أن ذلك جائز في الصناعة الشعرية،" "rآ ويـــهب قدامة في "نقد الشعر" المذهب نفسه؛ إذ قال: "إن الغلو عندي أجود المذهبين (الغلـــو و القصد)، وهو ماذهب إليه أهل الفهم بالشعر والشعراء قديماً، وقد بلغني عن بعضهم أنه قال: "أعذب الشعر أكذبه. "r"آ

وهذه المقولة تخالف نظرة الإسلام خخالفة صريحة، فالإسالام لم يجز الكذب في حال

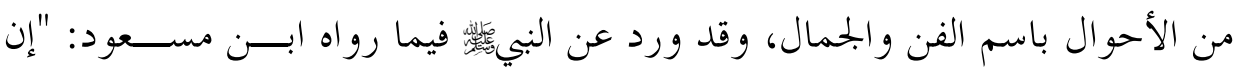

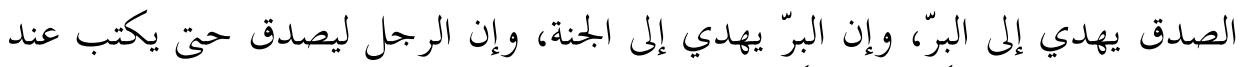

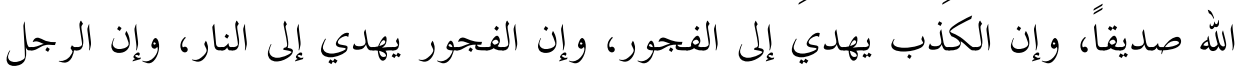

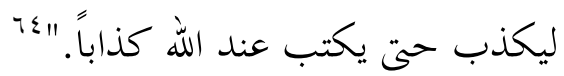

و من الذين أحسنوا في الرد على هذه المقولة العلامة عبد الرحمن حبنكة الميداني؛ إذ

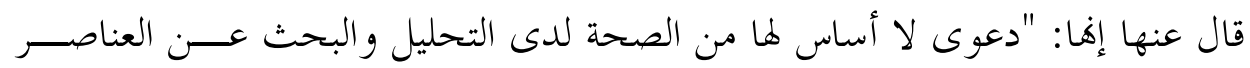

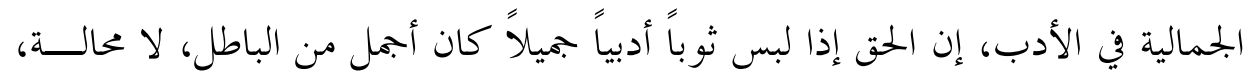

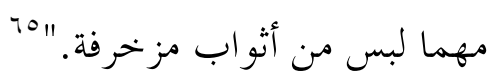

ثالثاً: القر آن بين جمال اللفظ وجلال المعنى ا ـ محال الأسلوب القر آني والفواصل:

إن القر آن الكريم معجزة قولية سجد المشر كون لروعتها و وجمالها، بَ ولقد وصــفه الوليد بن المغيرة حين سمع آيات منه بقوله: "والله لقد سمعت منه (الرسول عليه الصلاة

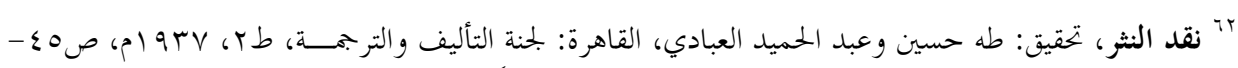

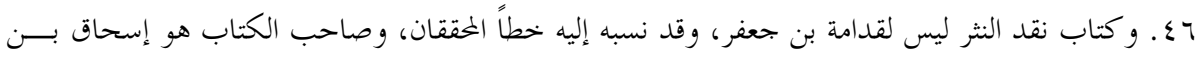

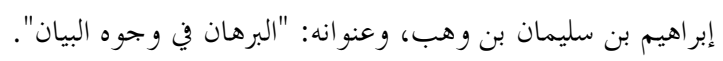

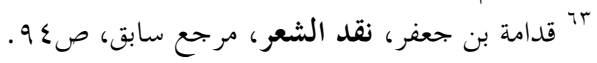

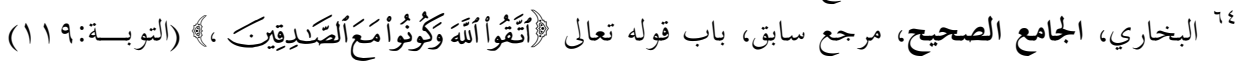

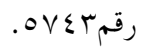

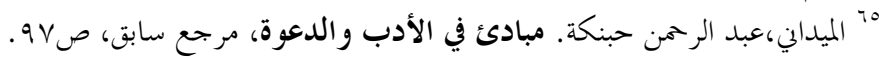

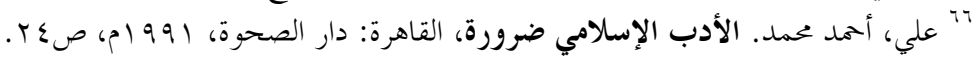


والسلام) كلاماً ما هو من كلام الإنس ولا من كلام الجحن، وإن له لحلاوة، وإن عليه

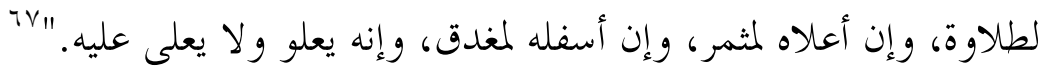

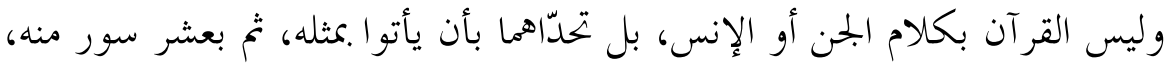

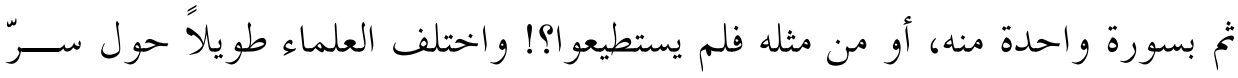

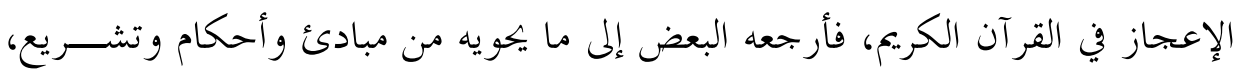

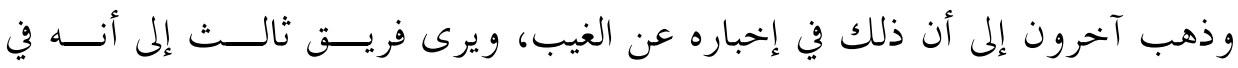

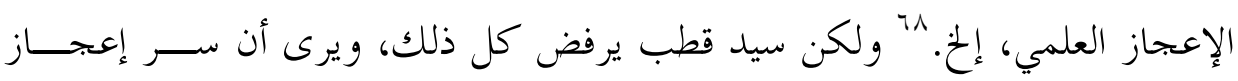

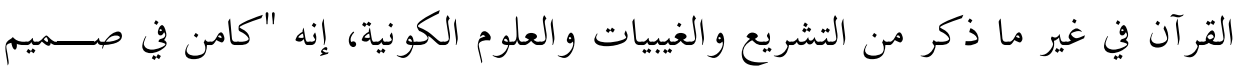

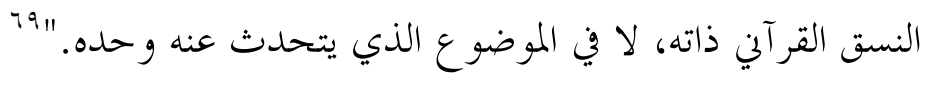

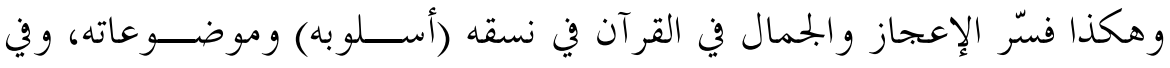

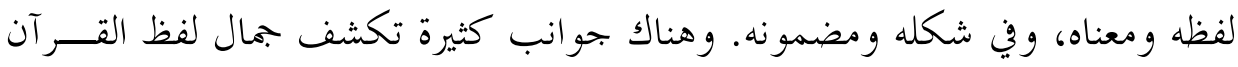

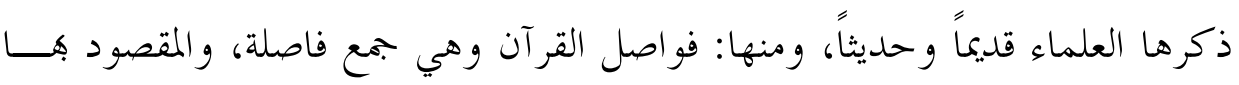

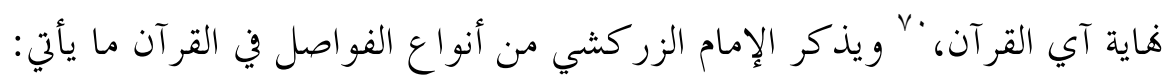

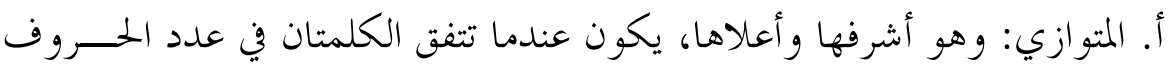

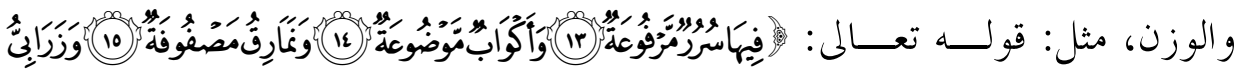

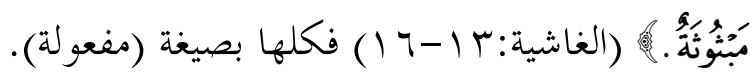

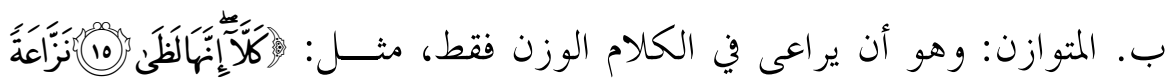

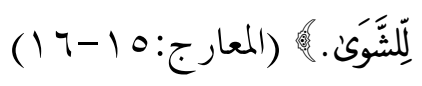

ج. المطرف: وهو الاتفاق في الحروف لا في الوزن ولا في عدد الحروف، مثــل:

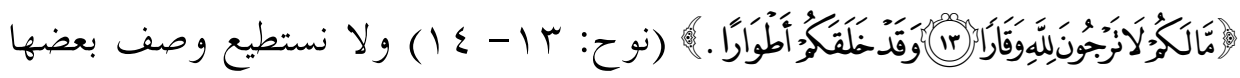

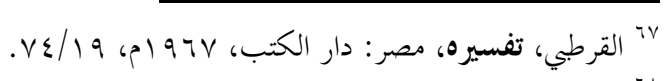

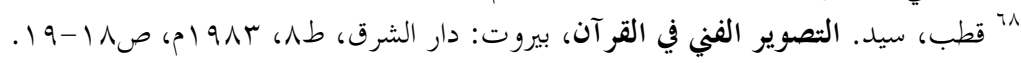

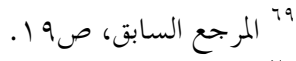

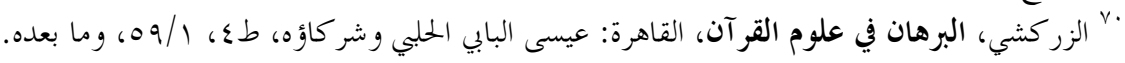




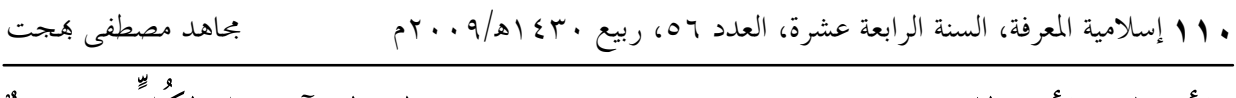

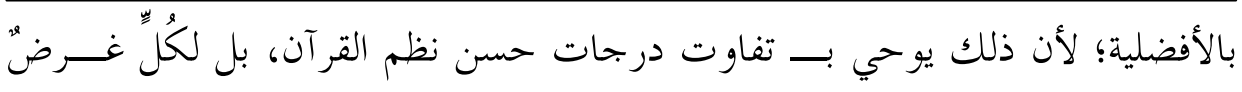
يؤديه، حسب مقتضى الحال.

و القرآن يراعي التناسب في الفواصل، فقد ذكر الزخشري أنه لا تحسن المحافظـــة بحردها إلا مع بقاء المعاني على سدادها على النهج الذي يقتضيه حسن النظم و التئامه، كما لا يحسن تخير الألفاظ المؤنقة في السمع، السلسة على اللسان إلا مع بحمئئها منقادة

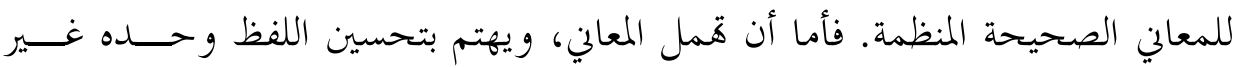

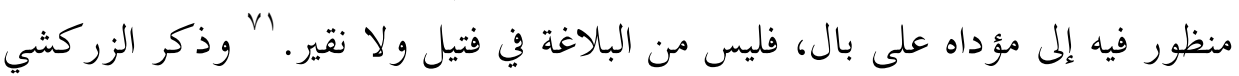

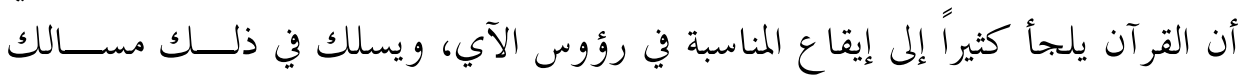

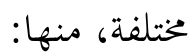

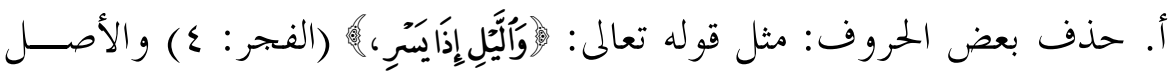
إذا يسري؛ ولكن لمناسبة رأس هذه الآية بالآيات السابقة حذفت لئت الياء.

ب. زيادة بعض الحروف: ومن ذلك إلحاق الألف (بالظنون) في قولـــه تعــالى:

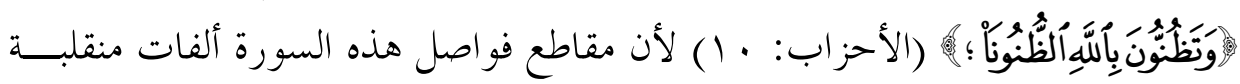
عن تنوين في الوقف، وقد زيدت الألف على النون في (الظنونا)؛ لتناسب هذه الآيـــة

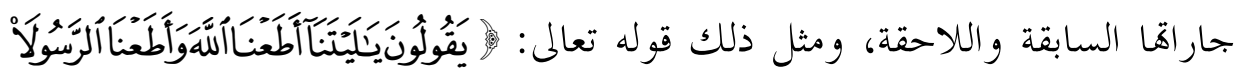

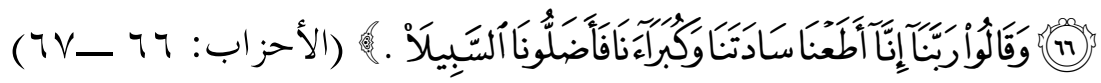

ولعل الألفات الثلاثة زيدت؛ لتصوير شدة الخوف والاضطراب الذي سيطر على المسلمين في غزوة الأحزاب، أما زيادة الألف على (الرسولا) و والسبيلا)؛ فهي لتصوير

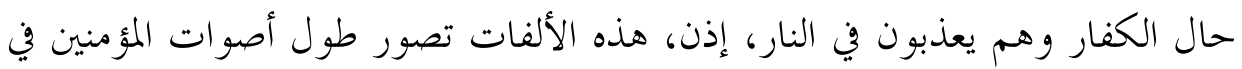
صياحهم الداخلي، وطول أصوات الكفار، وهم يصطرخون في النار. ويعلق الإمـــام

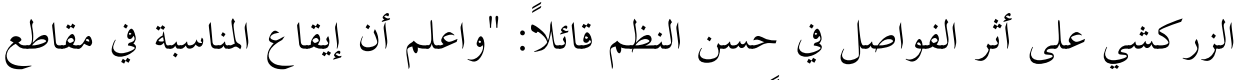

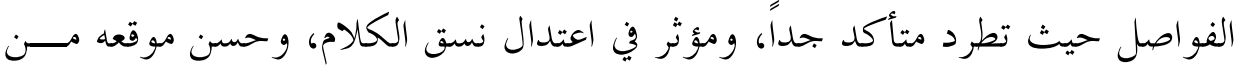
النفس تأثير اً عظيماً. 


\section{r. بو لوحات جمالية من القر آن الكريم:}

يجمع القرآن الكريم بين جمال اللفظ وجالال المعنى، فلا يطغى أحدهما على الآخر،

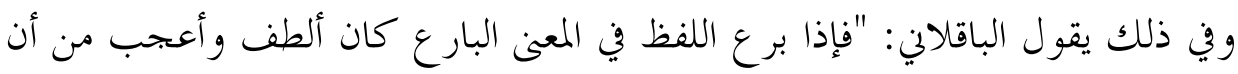

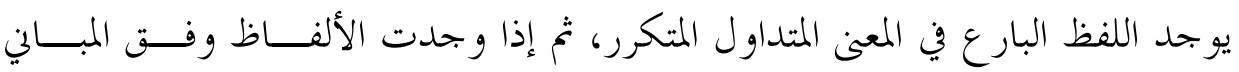
و المعاني وفقها... فالبراعة أظهر، و الفصاحة أتح..

و يقول أبو سليمان الخطابي (تح مشهـ) في ربط جمال لفظ القرآن في نظمه .كعناه: "واعلم أن القر آن إنما صار معجزاً؛ لأنه جاء بأفصح الألفاظ، في أحسن نظوم التأليف،

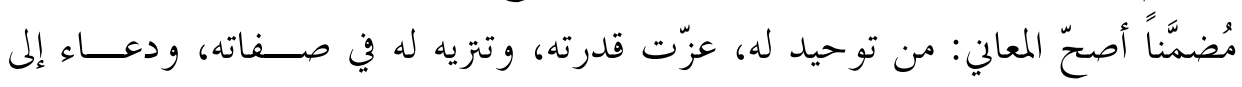

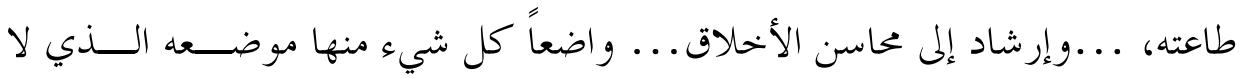
يرى شيء أولى منه، ...ومعلوم أن الإتيان هذذه الأمور، و الجمع بين شتاها حتى تنتظم

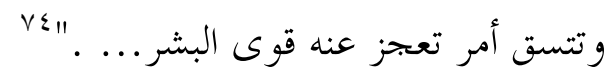

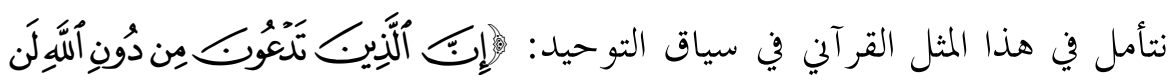

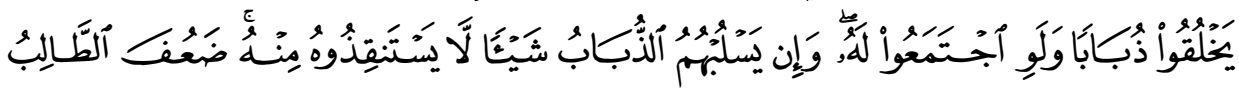

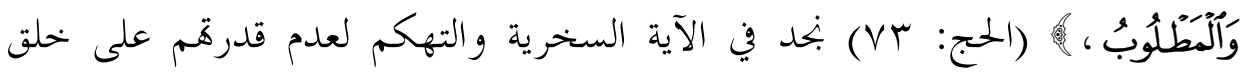
الذباب، وون جهة أخرى بحد العجز عن رد هذا المخلوق الضعيف، وذلك في قوله: (يسلبهم) و (لا يستنقذوه)، إنه البلاغة في التعبير. وأخيراً، نحاول عرض لوحتين من القرآن الكريم، ونحلِّهما مبيـنيـن تسلسـلهما وتتابعهما، فالصورة الأولى من مشاهد يوم القيامة للجنة، و الثانية للنار.

\section{أ. أ. من مشاهد الجنة:}

في لمحة خاطفة بعد الموت، ينفخ في الصور، فإذا الناس يخرجون من قبورهم،

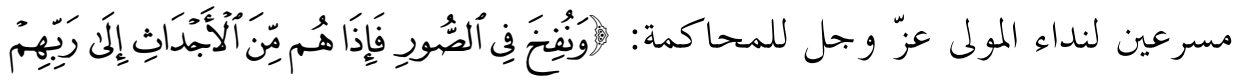

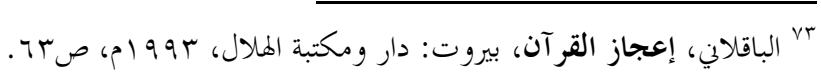

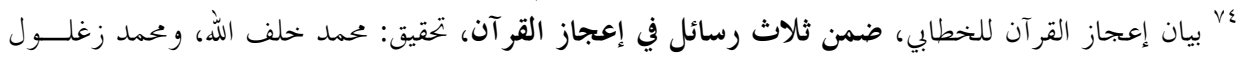




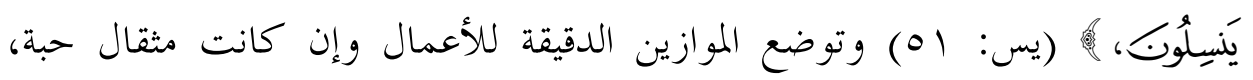

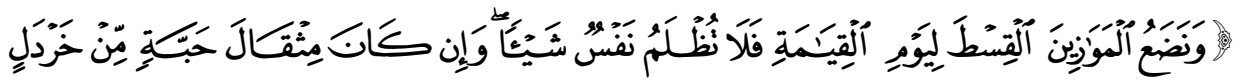

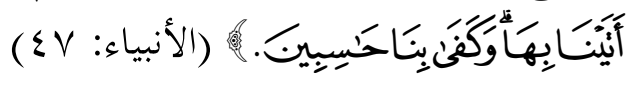

وتتم المحاكمة فيذهب كل فريق إلى مقره: المؤمن إلى الجنة، والكافر إلى النار.

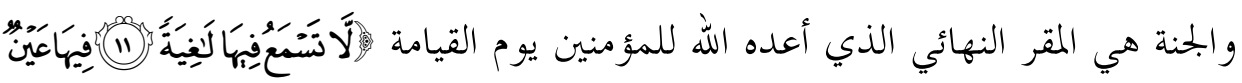

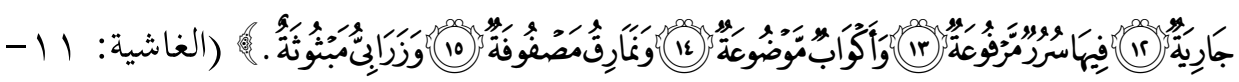

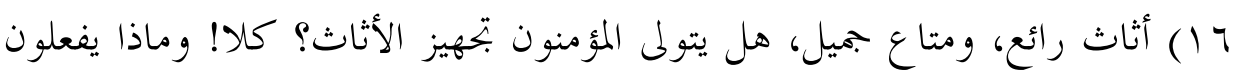

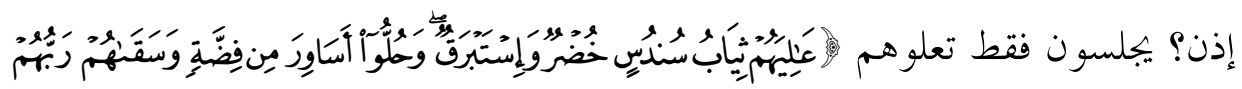

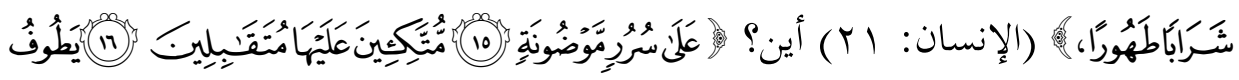

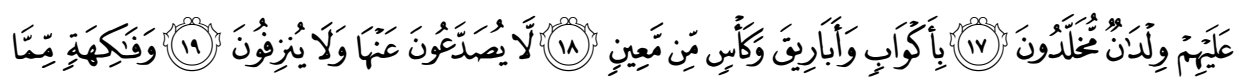

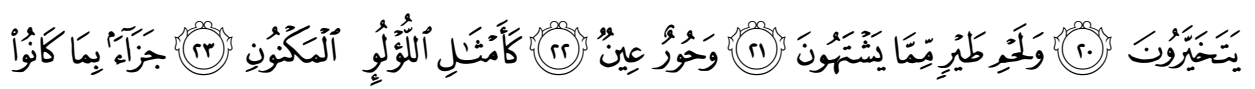

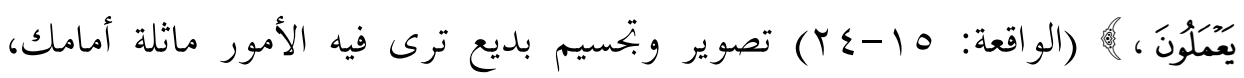
وتتشوق نفسك إلى التنعم هذه النعم، صورة مليئة بالنشاط والحيوية والحركة الدائبة: طواف، وذهاب وإياب، وحديث و كلام، وترى الكؤوس من المعين تلمع بصفائها وصفاء ما فيها من شراب.

\section{ب. من مشاهد النار:}

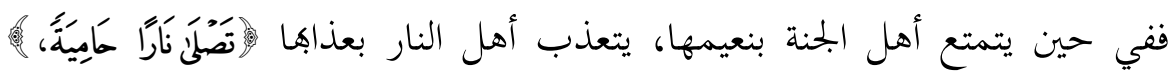

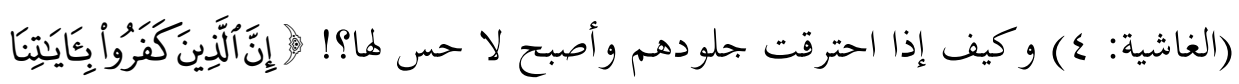

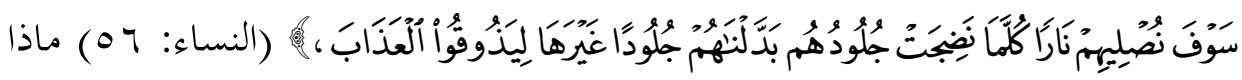

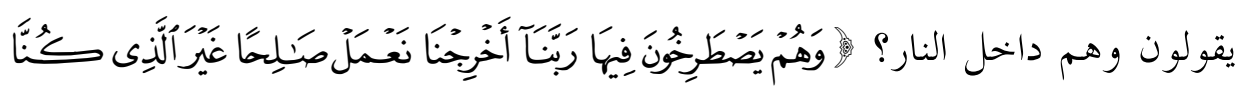

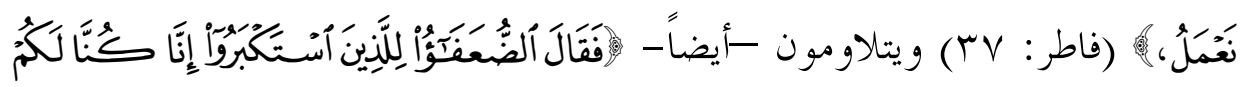




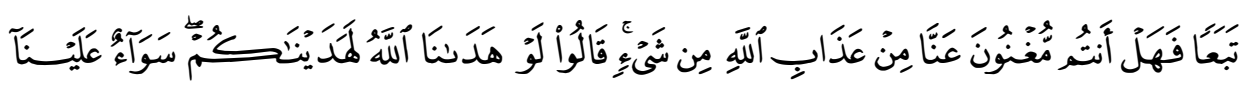

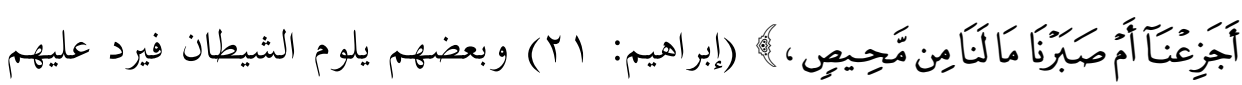

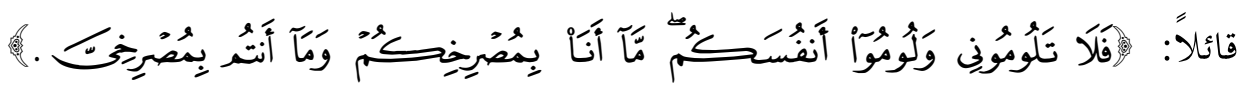
(إبراهيم:Y (Y)

هل لهم فيها من طعام أو شراب أو ظل مثل أهل الجنة في الجنة؟ نعــم، ولكـــن

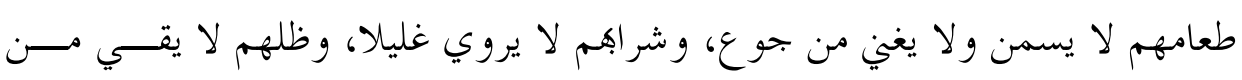

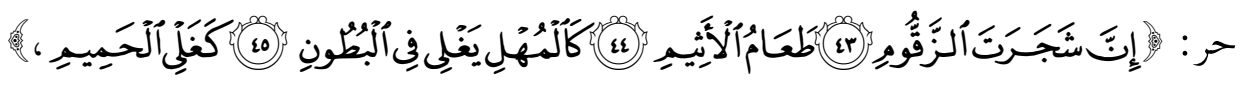

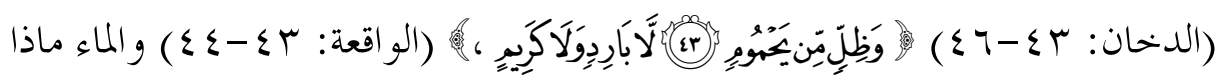

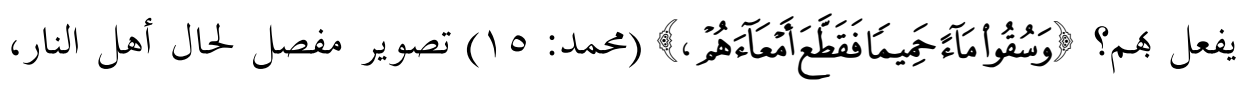

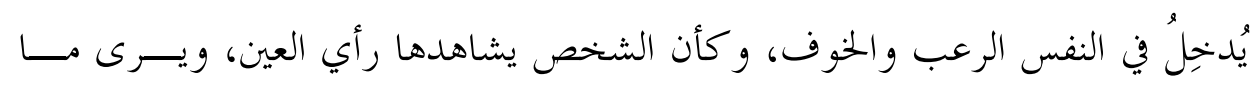
يقاسي أهل النار فيها.

خاتمة:

تناول البحث بعد تعريف الجمال والالتزام لغةً واصطلاحاً علاقة الإسلام بالجمال،

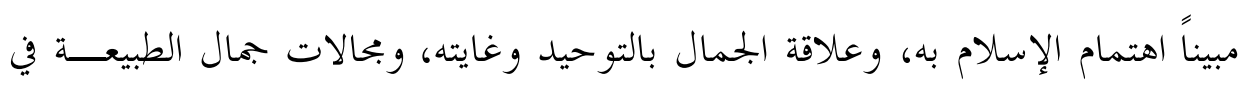

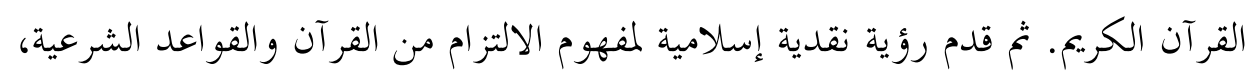

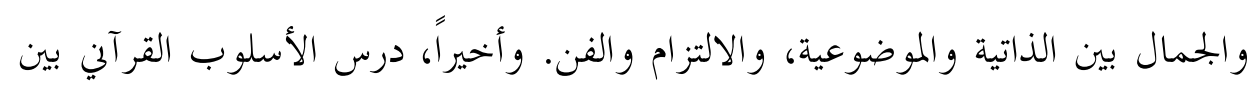

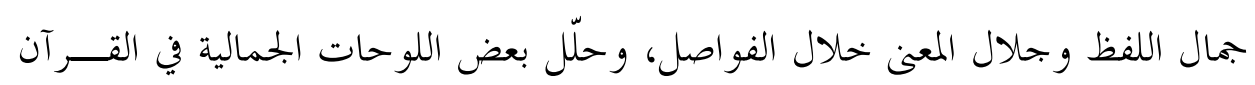
من مشاهد الآخرة: الجنة و النار. 


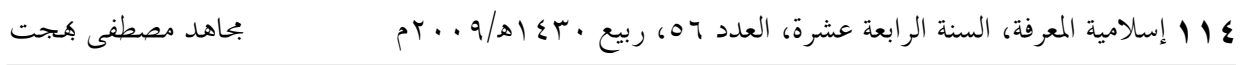

وقد رأينا أن الجمال نعمة من نعم الله وشعار في خلقه، وقد جبلت النفوس علــى

تذوقه و الابحذاب إليه، وإن تفاوتت في الدرجة، ومفهوم الجمال في الإســالام مفهـــوم واسع يشمل كل ما في الكون و الطبيعة والإنسان بشقيه: الماديّ، والمعنويّ.

و ما من شك أن الإسلام حرص على جذب انتباه الإنسان المســلم لاستشـــــاف

جمال صنع الله، و التمتع به، وتمثله في جميع سلو كه: الماديّ، والمعنويّ، وحرص الإسالام

-كذلك- على ضرورة مطابقة الجمال الظاهري بالجمال الباطي الحقيقــي، وذلــك بربط الجمال بالخير والحق والمنفعة، وعدم الفصل بينها.

وظهر لنا أن مفهوم مسؤولية الإنسان تتصل بأقو اله وأفعاله، لكــن الالتــزام في

الإسلام لا يحرم صاحبه من الحرية، على أن لا تخرج هذه الحرية إلى الفوضى والتحلل، بل تدعوه إلى السمو و الرقي و بلوغ المعالي.

كما لاحظنا أن الخروج على القيم الخلقية والروحية باسم استقلال الفن، مفهوم يخالف روح الإسلام، المبني على قواعد الأخلاق الكريمة و المسئولية والالتزام. 